\title{
The Multidimensional Structure of Taste
}

A Cultural Legitimacy Based on Interactions Between Education, Age, and Gender

La structure multidimensionnelle des goûts. Une échelle de légitimité culturelle fondée sur les interactions entre diplôme, âge et sexe

\section{Camille Noûs, Nicolas Robette and Olivier Roueff}

\section{(2) OpenEdition}

Electronic version

URL: https://journals.openedition.org/bssg/625

DOI: $10.4000 /$ bssg. 625

ISSN: 2490-9424

\section{Publisher}

Presses universitaires de Vincennes

\section{Electronic reference}

Camille Noûs, Nicolas Robette and Olivier Roueff, "The Multidimensional Structure of Taste", Biens Symboliques / Symbolic Goods [Online], 8 | 2021, Online since 20 May 2021, connection on 23 July 2021. URL: http://journals.openedition.org/bssg/625 ; DOI: https://doi.org/10.4000/bssg.625

This text was automatically generated on 23 July 2021

Biens Symboliques / Symbolic Goods 


\title{
The Multidimensional Structure of Taste
}

\author{
A Cultural Legitimacy Based on Interactions Between Education, Age, \\ and Gender
}
La structure multidimensionnelle des goûts. Une échelle de légitimité culturelle fondée sur les interactions entre diplôme, âge et sexe

Camille Noûs, Nicolas Robette and Olivier Roueff

Translation : Katharine Throssell

Fig. 1.

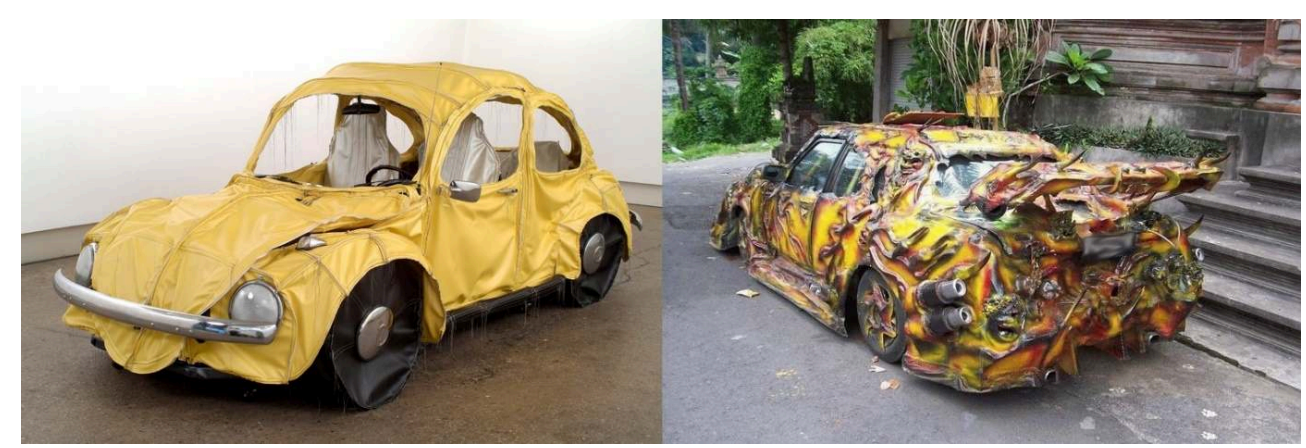

Source: Left: , 2004. Right: Published on February $18^{\text {th }} 2010$ on Ze Jacky Touch

1 Since the early formulations in the 1960s (Bourdieu \& Passeron 1979 [1964]), the notion of cultural legitimacy has been through several incarnations and been subject to numerous criticisms. The publication of Bourdieu's La Distinction was a milestone (1979 for the French, 1984 for the English translation), with its imposing and complex empirical framework revealing the ordering of legitimacies of a large range of lifestyle aspects in the social space of metropolitan France. It revealed the tripartite structure of lifestyles in terms of the volume, composition, and age of cultural and economic capital. The book ultimately cemented the study of attitudes towards culture within an analytic framework that went beyond simply recording inequality of access or the 
social distribution of taste. The notion of cultural legitimacy was borrowed from Weber's concept of legitimacy (Weber 1978) to conceptualise the culture associated with upper classes - and more specifically their intellectual elements - as dominant. The scale of cultural legitimacy is therefore defined by the homology between the symbolic hierarchy of cultural practices, and the social hierarchy of the social groups who practice them. Thus, legitimate culture is not only the culture that is valued within the upper classes - even though it is in the minority there too - but it is also the authoritative culture outside that sphere. It exerts "symbolic violence" and constitutes a reference point for the social space as a whole, including in the form of awkward acceptance (the "cultural goodwill" of the well-educated lower middle class in Distinction), polite acquiescence, defensive rejection, or irrepressible shame. Ultimately, it obviates indifference and any reaction to it, even critical, must be interpreted as a recognition of its social value, symbolic weight, and prescriptive power.

2 To this uniformly prescriptive scale covering the whole social space, Claude Grignon and Jean-Claude Passeron (1989) opposed the ambivalence of popular practices, far removed from the bourgeois source of legitimacy, which are either brushed off as secondary, as devoid of cultural value, or valued according to alternative symbolic criteria that are relatively autonomous from the dominant ones. This ambivalence about the value of social practices is associated with the ambivalence of scholarly perspectives that alternate between miserabilism (which only sees in popular culture its distance from legitimate culture and its symbolic deprivation) and populism (which only sees the autonomy of alternative attitudes towards symbolic values and goods, and an enchantment of authentic working class culture). This ambivalence of perspectives can be seen partly in the different possibilities of investigative methods. The statistical analysis of large bodies of data relating to the cultural tastes and practices of people in metropolitan France above all reveals the relative estrangement of respondents to the terms of the questionnaire, i.e. toward "culture" in the sense that can only lend support to its legitimist definitions. This statistical weight of the very small minority of dominant classes which constitutes the source of dominant symbolic prescriptions is therefore increased, and the vast dominated majority can essentially be seen between the lines, as nonpracticing or rarely practicing. Inversely, ethnographic studies that intensively explore the values and practices of a specific population almost mechanically emphasise (because of the saturation of qualitative observations in a relatively homogenous environment) the specificity of that environment and the way in which its alternative foundations escape the influence of what stands beyond direct observation, even when this beyond is also at a socially higher level.

3 These questions are now well known and are integrated into an increasing number of studies, year in year out, whether ethnographies on power relations focused on cultural capital (Mauger, Poliak, Pudal 2010; Serre 2012), or statistical studies on specific spheres of practice (to cite just a few, Baudelot, Cartier, Detrez 1999; Coulangeon 2003; Duval 2016). Yet, to the best of our knowledge, since Distinction itself there has been no quantitative analysis of cultural legitimacy conducted for metropolitan France ${ }^{1}$ and for several cultural practices studied together. ${ }^{2}$ In a previous article (Robette \& Roueff 2017) based on the survey Pratiques culturelles des Français (Cultural Practices of The French, abbreviated as PCF), conducted in 2008 by the Department of Prospective, Studies, and Statistics within the Ministry of culture (PCF 2008), ${ }^{3}$ we demonstrated that it was possible to, if not entirely account for the relative autonomy toward dominant 
culture, then at least to establish a scale of legitimacy that orders the distribution of tastes for the social space as a whole, including within the popular classes. This study also showed that a "legitimist" questionnaire analysed using correspondence analysis, which gives additional weight to small populations (and thus legitimate culture), did not prevent the observation of the signs of relatively autonomous symbolic spheres in the working classes. It was however not possible to decisively establish an explanation in terms of incompetence (insufficient mastery of legitimate rankings), indifference (a way of avoiding the effects of legitimacy), or relative autonomy (alternative principles of cultural hierarchies specific to the working classes).

4 And yet the analysis conducted for this previous article gave rise to a question that had been neglected in empirical statistics - given that the cultural legitimacy scale is constructed through the homology between the hierarchy of taste and the hierarchy of social groups, what social space does it refer to? Investigating the prescriptive force of the culture of dominant classes, our analysis therefore captured social space essentially in terms of the distribution of economic and cultural capital based on socioprofessional categories and educational qualifications. Yet it is now well established that cultural tastes simultaneously respond to other logics of differentiation, particularly those related to age and gender (Bennett, Savage, Silva, Warde, Gayo-Cal, Wright 2009; Christin 2012; Coulangeon 2003; Donnat 2005, 2011; Detrez 2011; Octobre 2011; Roose, van Eijck, Lievens 2012; Albenga et al. 2014). Other studies have approached this question by opposing the class positions to other structural factors (such as education, age, gender, etc.) in order to evaluate the weight of their respective impacts on the hierarchy of tastes and legitimacies. Certain researchers consider that the explanatory power of class relations in the development of tastes is overestimated as far as theory is concerned (Macé \& Maigret 2005), or at the very least it is overinterpreted based on statistical differences which do not really cleave the data (Fabiani 2007 ; Pedler \& Ethis 2001). Others hypothesise that this may have been true at the time Distinction was written but is now empirically unlikely, particularly given the effect of the democratisation of schooling and the hegemony of cultural industries - particularly those which produce "youth culture" (Pasquier 2005) or "cultural dissonance" (Lahire 2004). The hypothesis of an increase in cultural omnivorism as the new legitimate norm (Peterson \& Kern 1996; Peterson \& Simkus 1992) is itself marked by this debate. Are we witnessing the weakness of the social hierarchy of tastes (Glévarec \& Pinet 2009), or the redefinition of the model of legitimate culture with the decline of classical exclusivity (Coulangeon 2003; Donnat 1994; Savage \& Gayo 2011)? ${ }^{4}$

5 These studies often share a reasoning that proceeds variable by variable in observing the differences in tastes successfully correlated with indicators of class, gender, and age. This is also true of the two major studies that modelled themselves on La Distinction to study the spaces of lifestyles in Great Britain (Bennett et al. 2009) and in Aalborg (Denmark) (Prieur et al. 2008). As Duval noted (2011), the first study used geometric data analysis (GDA) to reduce the information without really making the most of its multi-dimensional nature. It was limited to a simple observation that the first axis was structured around an opposition between "snobbish" and "vulgar" culture, which was correlated to class position (but without studying the composition of capital), while the second axis was structured around an opposition between recent and established culture, correlated with age, and a third axis represented an opposition between public and private, correlated with gender. Similarly, the Danish study contented itself with noting that women and young people were concentrated in the area of the analysis of 
tastes with the strongest correlation to high levels of cultural capital. As for the studies that explore the articulation between these variables, mentioned above, they exclusively do so to test their respective weights, to play them off against each other, and not to really observe the effects of their interactions.

The statistical construction of the scale of cultural legitimacy is, by definition, based on the hypotheses that there is a homology between social positions and cultural position takings; tastes considered illegitimate are correlated with lower social status positions, legitimate tastes are correlated with higher social positions. These correlations are relative in the sense that, for example legitimate tastes may in fact be secondary in higher status groups and simply more often associated with these groups than with others. These are indeed associations and homologies. Statistical analysis cannot demonstrate the existence of homologies between social spaces and spaces of tastes but only observe how the one is distributed according to the other - and it can demonstrate the existence of homologies either between fractions of the social space, or between different areas of practice (on this point see, Robette \& Roueff 2017). Statistical analysis cannot demonstrate the existence of legitimacy effects beyond relying on two kinds of indicators. The first is the expression of distaste, when the questionnaire allows it, by members of the dominant group concerning tastes that are strongly preferred in dominated groups. This can be interpreted as an indicator of an attempt at distinction, or an attempt to produce legitimacy effects. With the second, we can demonstrate that the tastes that are strongly associated with the dominant categories polarise the space as a whole but also, if we narrow our focus, the spaces specific to each group within the social space, even the most dominated (Robette \& Roueff 2017).

Our goal is therefore to use the PCF 2008 study, which is representative of the French population, to empirically construct the social space of tastes according to a legitimacy scale, by using indicators of an individual's position within several social power relations, specifically class, age, and gender. In other words, is it possible to statistically take into account the plurality and intersectionality of social power relations (class, race, gender, according to the traditional triptych, but also age, location, health, etc.) that numerous ethnographic studies (for example Skeggs 1997; Khan 2011; Avril 2014; Le Renard 2019) have now documented at the level of individuals and social groups? Moreover, how can we analyse the correlations between the variables of social position without falling into the unproductive trap of constructing a hierarchy of effects rather than studying their interactions? Our hypothesis is that cultural legitimacy is defined at the intersection of social power relations overall, here reduced to three statistical indicators for education, age, and gender. Not only do the "snobbish" (intellectual upper middle class), the "established" (traditional, classical, old) and the "elegant" (feminine by opposition with masculine vulgarity ${ }^{5}$ ) operate together to define the criteria of good taste - indeed, good taste is more often associated with university educated, older women - but the combined effect of these principles of distinction differs from one end of the scale of legitimacy to the other, such that the lower levels are more often associated with low levels of education but also older women.

We will begin by presenting the problem through an observation of the shape of the legitimacy scale as it can be constructed based on the homology between the factorial projection of social positions and that of tastes in terms of reading, cinema, music, and television (1a). We therefore develop two characteristics of this legitimacy scale. On the one hand it is not only sensitive to the axis associated with economic and cultural 
capital (an axis which has been widely identified), but it is also sensitive to the axis associated with variables of age and gender. On the other hand, this scale is not linear; it does not follow a straight line, even diagonal, within the factorial space, but rather a "flat U" (1b). In other words, the "effects" of the variables differ according to the categories of other variables with which they interact. Once the problem has been established and defined, we go on to consider three ways to narrow down the expected results, emphasising the limits and contributions of each. A hierarchical agglomerative clustering enables us to specify the configurations of the categories that are the most correlated with each other. Close attention to the threefold association of tastes with education, age, and gender, therefore allows us to avoid incorrect interpretations of this typology, such as those which would consider "average" tastes instead of the most legitimate tastes (2a). The scale of cultural legitimacy previously identified and its curved form are thus reinforced, and the benefit of studying the effects of one variable by opposition with the effects of other variables is weakened, to the benefit of studying their interactions. Therefore, projecting synthetic variables that combine the categories of education, age, and gender, on to the factorial space of tastes allows us to describe the interactions between these three variables and show why they form a parabola, in other words, why they do not act in the same way at different points on the scale of legitimacy $(2 b)$.

\section{A Curved Scale, Sensitive to Economic and Cultural Capital as well as Age and Gender}

\subsection{Principles of Construction}

Few studies have set out to empirically construct a scale of cultural legitimacy, and when they have, they have used very different indicators and statistical techniques (Robette \& Roueff 2014). Yet the principle is simple: by definition, the scale consists in ordering indicators of lifestyle (here cultural tastes) according to indicators of social position (Bourdieu 1984). Among the various approaches available, we have chosen to use geometric data analysis because it allows us to simultaneously mobilise several indicators of both taste and position, ${ }^{6}$ and thus minimise the deleterious and sometimes divergent effects of selective choices (Robette \& Roueff 2014). Among these methods we use multiple factor analysis (MFA) developed by Brigitte Escofier and Jérôme Pagès (2008) because we are dealing with data on tastes in terms of cinema, reading, music, and television, which are the areas that are the most well documented within the study on the cultural practices of the French conducted in 2008 (PCF 2008). ${ }^{7}$ The active variables are the variables of taste. We are observing the way they are ordered independently of social characteristics, and then projecting the variables of social positions as supplementary variables ${ }^{8}$ in order to study the way in which they "overlap" with tastes. MFA allows us to balance how much the different groups of variables (each corresponding to the four areas of tastes mentioned above) contribute to structuring the factorial space so that an area that is particularly polarized, or contains a much larger number of variables and categories does not artefactually weigh more than the others.

Multiple Factor Analysis (MFA) and Specific Multiple Correspondence Analysis 
Technically, MFA is like doing multiple correspondence analysis (MCA) for each area of taste separately, bringing the coordinates of individuals on the axes of these MCAs together and conducting principle component analysis (PCA) based on these coordinates, weighted by the variance of the first axis of that area. Thus, MFA accounts for the connections within each area as well as the connections between areas. It is therefore a way of overlapping the four spaces of taste using a statistical tool designed for this rather than by hand or using a simple MCA that is indifferent to the equilibrium between areas. ${ }^{9}$ Moreover, all the multiple correspondence analyses conducted are "specific". This means that some of the categories of the active variables are made passive so that they do not contribute to the construction of the space. For example, this is the case for less interesting categories (such as "other" or "non response") or those with small population sizes, which would otherwise weigh unnecessarily on the construction of the space (Le Roux \& Rouanet 2004). To conduct these analyses we used the software R and the GDAtools package which include, among other things, all the tools for geometric analysis mobilised here.

Fig. 2. The space of tastes for cinema, reading, television, and music (MFA)

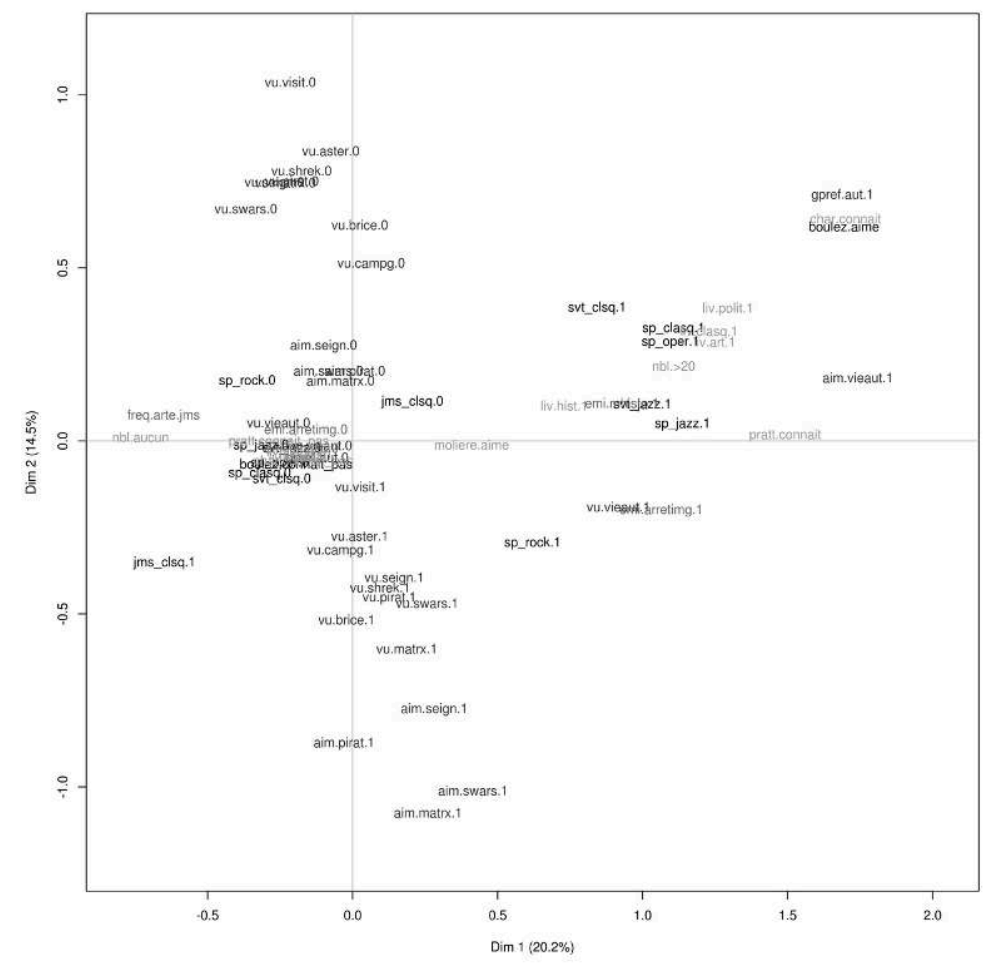

Note: To make reading easier, only the categories most strongly associated with axes 1 and/or 2 are represented here. The full labels and corresponding abbreviations are available here (Robette \& Roueff 2017, Appendix 1)

Source: Cultural Practices of the French (Pratiques culturelles des Français 2008 - DEPS)

Detailed analysis of this space of tastes has already been published accompanied by more in-depth justifications of the methodological choices as well as more readable graphic representations (Robette \& Roueff 2017). We will not return to this in detail here, but merely rapidly observe the main factors of differentiation and the overall 
shape of the distribution of the categories of tastes and social properties, before focusing our attention more specifically on the study of interactions that constitute the scale of legitimacy.

11 The first axis represents an opposition between non-practice (for example "no books read") and the most widespread practices (watching the soap opera Plus Belle la Vie) on the one hand, and the most esoteric practices on the other (for example reading the newspaper Le Monde or listening to the music of Pierre Boulez). The second axis represents an opposition between emerging (reading graphic novels or watching the TV series Prison Break) and/or masculine practice (action films as a preferred cinematic genre), and established (watching the state-owned television channel France 3) and/or feminine practices (referring classical music or romance novels). These descriptions are of course related to each other - graphic novels are more "emerging" (more recently integrated into cultural heritage) than novels, action films are "more masculine" than romantic comedies, and so forth. ${ }^{10}$ And they are of course not mutually exclusive, action films are also "more juvenile" and classical music more "bourgeois". This is exactly what we wish to emphasise here, and our goal is simply to characterise the different axes of the MFA using certain suggestive categories as an illustration.

12 To extract the scale of cultural legitimacy, we then need to project our supplementary variables, which are the variables of social position (socio-professional category, education, income, age, gender, assets), onto this space of tastes and observe how they are organized..$^{11}$ 
Fig. 3. Projection of supplementary variables of social position onto the MFA of tastes it terms of television, cinema, reading, and music

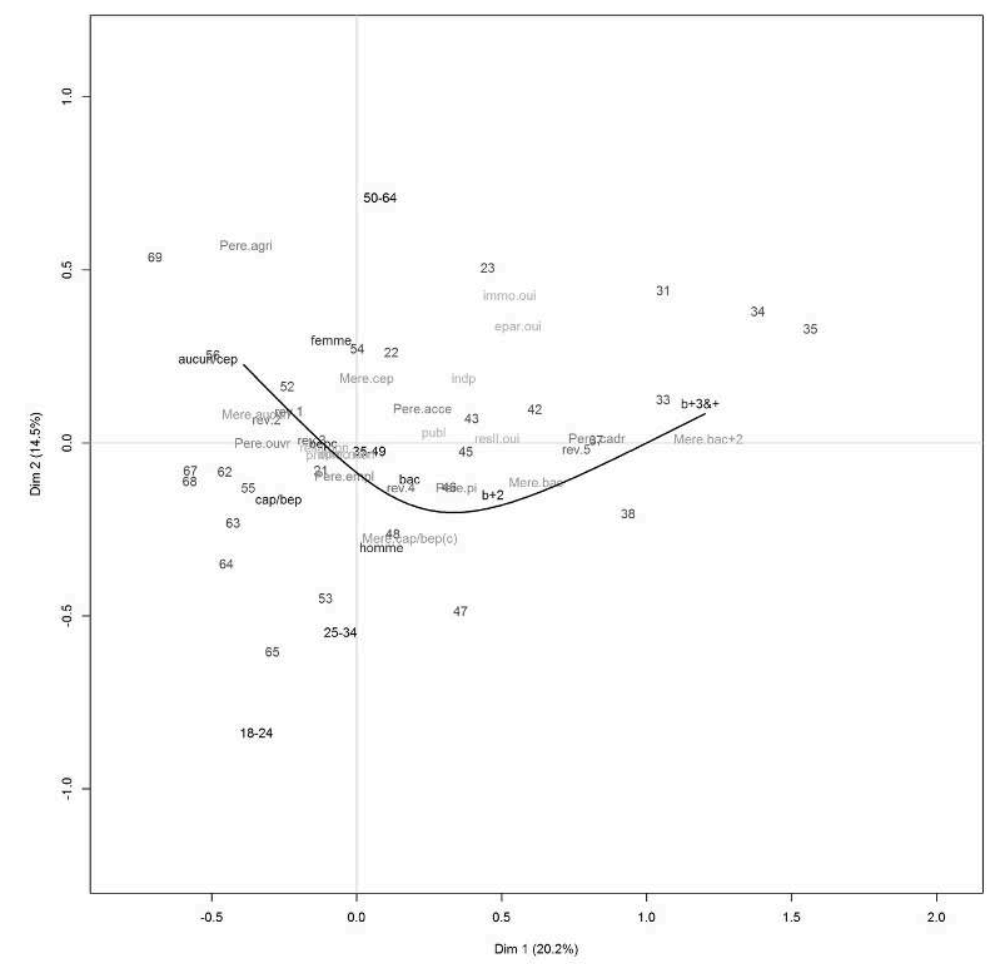

The curve was drawn manually to help visualise the "curved" alignment of the categories.

Source: Cultural Practices of the French (PCF) (DEPS). Key: The 24 socio-professional categories (SPC) are noted by their double-digit code; these variables also include gender and age (15-17; 18-24; 25-34; 35-49; 50-64), employment status ("publ"= public sector employment; "priv"= private sector employment; "indp"= independent), educational level ("aucun/cep"[none/primary school;; "cap/ bep"[vocational]; "bac" [high school certificate]; " $b+2$ " = bac+2[ high school certificate +2years post

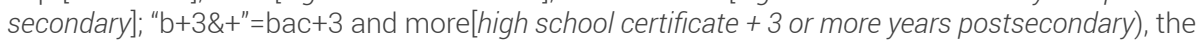
household income ("rev" [revenue] followed by the quintile as a suffix), mother's educational qualification ("mère" [mother] with the educational level as a suffix), the father's profession ("père" [father] followed by SPC coded into 6 categories), holiday home ownership ("resII" [secondary residence] suffixed with "oui/non" [yes/no]), possession of family real estate assets ("immo" [property] with the suffix "oui/non" [yes/no] ) and the possession of savings ("epar" [savings] with the suffix "oui/ non", [yes/no]). For more details see https://sociologie.revues.org/3275 (Appendix 1 of Robette \& Roueff 2017).

\subsection{A U-Curve: Interactions Between Capital, Age, and Gender}

In factorial spaces of this kind, the first axis (the $\mathrm{x}$-axis in Figure 3) is generally considered a representation of the legitimacy scale because it is essentially correlated to indicators of the volume of economic and cultural capital. It is indeed a good approximation, as we can see in Figure 3. However, it is possible to be more precise if we observe the exact distribution of the supplementary variables of social position. Economic and cultural capital are closely correlated to the first axis while the second is correlated with age and gender. ${ }^{12}$ But they are not strictly aligned with these axes, which is not very surprising given that economic and cultural capital are not perfectly independent of age and gender. Instead it is the effect of this interaction on the overall morphology of the space that should be studied more closely. Indeed, all the class variables, which are quite closely aligned with each other, form an "elongated U" shape 
running from the upper left quadrant to the upper right quadrant via the bottom of the space. ${ }^{13}$ Moreover, it is the cultural capital variables that are the most dispersed along this curve. Given that the distribution of socio-professional categories is particularly sensitive to gender, broadly speaking we traditionally observe feminine professional spheres in the upper quadrants (employees, service sector, intermediary professions in health and social work, teachers, etc.) and masculine professional sectors in the lower quadrant (engineers, skilled and unskilled workers, technicians and foremen, etc.). But if we follow the curve we move from unskilled workers and employees to skilled workers, then to intermediary professions, and finally to managers and executives.

If, armed with this knowledge, we return to the space of tastes (Figure 2), we can clearly see this same "elongated U". Following the curve we move from "non-practices" as well as the most widespread, most established, and most feminine tastes in the upper left quadrant, to the more intense and more esoteric practices in the upper right, via the practices that are neither vulgar nor sophisticated, but are emerging and masculine in the lower part of the space. ${ }^{14}$ Ultimately, the dominant scale of cultural legitimacy defined by the homology between the distribution of capital, particularly cultural capital, and the distribution of tastes consists in a $U$ curve that is sensitive both to the axis of class relations and the axis of age and gender relations. This does not challenge the usual interpretation of the statistical distribution of tastes, identifying the dominant scale of legitimacy with the first axis, as far as multiple factor analysis is concerned, or with the simple organisation of tastes according to class variables. On the contrary, here we confirm that these are good approximations. What this study of the dominant legitimacy scale contributes, is the sign that this scale is made up of gender and age assignations without these variables being associated in strictly linear terms (which would be the case for example if the legitimacy of taste increased with the level of education and with age simultaneously).

\section{What Social Space is a Homologous With the Space of Tastes?}

The goal of the following analyses is on the one hand, to confirm the benefit of considering the social space that is homologous with the organisation of tastes as being constituted of interactions between education, age, and gender, and on the other hand to find statistical ways of describing the interactions between these variables in detail, and in particular their variations at different levels of the legitimacy scale. Henceforth we will use educational attainment as the only indicator of class position, for three reasons. Firstly, it is the most powerful discriminator in terms of class, and the most closely correlated with axis one (the x-axis in figure 3). Secondly, the other indicators of class are almost perfectly aligned with education. Finally, the objective of the analysis is to establish the existence and form of interactions between several social power relations associated with cultural legitimacy, whilst leaving a closer exploration of the categories (as well as the study of socio-historical explanations of the multidimensionality of cultural legitimacy) to a later stage of the study. It is for these same reasons that here we do not explore what age - the distance from an individual's birth year - means in terms of position in the life cycle, or generational belonging (Donnat 2011): it is sufficient to demonstrate that the social relations of age interact with those of class and those of gender. 


\subsection{A Scale Enriched by HAC Classification: Joint Effects of Education, Age, and Gender}

Observations of interactions between age, gender, and education should be visible in the results of a hierarchical agglomerative clustering (HAC), conducted based on individual coordinates on the first two axes. The advantage of this method - if it converges with the first - is to provide depth to the interpretation of different echelons of the legitimacy scale because for each class of the typology it clusters configurations of categories that are richer and more precise than visual clusters of Figures 2 and 3. A visual study of the dendogram as well as an analysis of the clusters that result from it suggests a partition into six clusters. We therefore begin by projecting the concentration ellipses of the six clusters obtained through HAC, onto the MFA (Figure 4).

Fig. 4. Projection of the HAC cluster concentration ellipses on the MFA

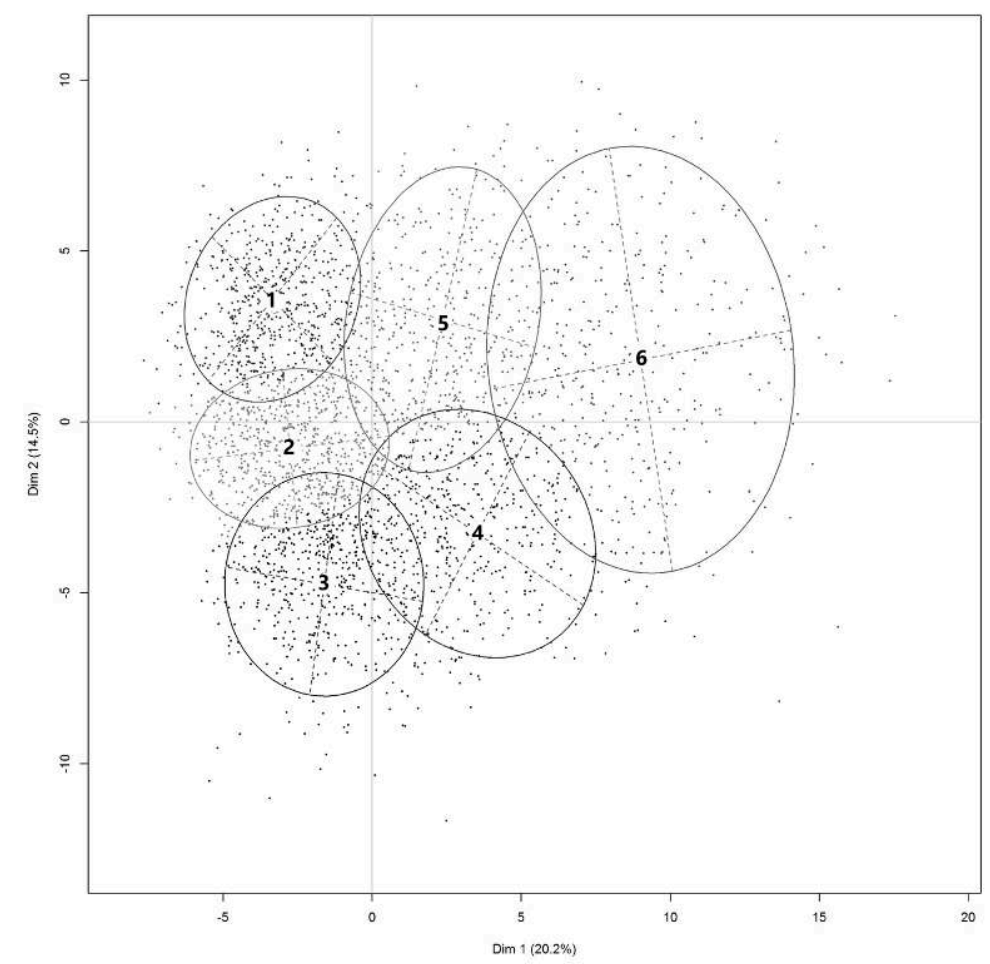

Source: Pratiques culturelles des Français 2008 (DEPS)

The reading of the graph seems straightforward on face value if we content ourselves with the approximation of the legitimacy scale using axis 1 . This would leave us with three lower class cultures: one masculine and emerging (3), one middle-aged (2) and one that is older and feminine (1). Then there are two intermediary clusters: one masculine and emerging (4), and the other feminine and older (5). And finally, there is a bourgeois cluster, which is slightly feminine and older (6). The preceding analyses should set us on a more interesting path however - is not our U-shaped legitimacy scale also visible here? With cluster 1 at the bottom of this scale (i.e. in the upper left-hand quadrant of the space), then the two and three, then four (in the lower space) and 
finally two variants of legitimate culture with clusters five and six (in the upper righthand quadrant)?

So, let us observe the categories that are significantly correlated to each cluster. ${ }^{15}$ Cluster 3 (see Appendix 1, Table 3) is firstly defined by tastes to do with music and television and, to a lesser extent cinema. Here we see the largest consumption of music and television, comparatively frequent cinema going (5 to 11 screenings annually, not the highest consumption) and very low levels of reading. The tastes that are overrepresented can be described as working class, emergent and masculine - rap and electronic music, mass public television shows on TF $1^{16}$ and secondarily the masculine markers such as Stade $2^{17}$ and the series Prison Break, action and science fiction films, as well as the rejection of musical comedy and romance films, an episodic relation towards books focused on graphic novels. These three descriptions are homologous with the social characteristics most associated with this very homogenous cluster: working class young men with low levels of education. It is the association between gender and age that is the most significant, for this is what distinguishes this pole from the other poles within the working classes. Youth probably explains the comparatively higher consumption of cinema (Duval 2011).

Cluster 1 (Appendix 1, Table 1) is characterised primarily by distance from cultural practices, inversely proportional to the assiduous consumption of television. In this area, the overrepresented tastes are popular, established, and feminine: the soap operas, The Young and the Restless ${ }^{18}$, Plus Belle la Vie ${ }^{19}$ and Dallas but also programmes like the French adaptation of Who wants to be a millionaire? ${ }^{20}$, Des chiffres et des lettres, ${ }^{21}$ Le plus grand cabaret du monde, ${ }^{22}$ and TV Shopping, all on TF1 and France $3 .{ }^{23}$ The same profile can be seen in other areas: romance films, romance novels, French pop music, ${ }^{24}$ celebrity or TV magazines - with a significant rejection of the action and science fiction films that are appreciated at the more masculine and younger pole of the working classes (cluster 3). In this respect cluster 1 represents the older feminine pole within the working classes, although the association between the variables of gender and age is less uniform than in cluster 3. Here older men and middle-aged women are also overrepresented.

Cluster 2 (Appendix 1, Table 2) is characterised by high levels of consumption of television and music and lower consumption of books and cinema. In terms of television, we observe the same popular tastes as clusters 1 and 3, without the markers of masculinity or femininity that characterised them. In terms of music, those in this cluster tend to listen while doing something else (in the background) and prefer international pop music that is both popular and emerging (compared to more traditional French "variety" pop music). In terms of cinema, their preferences range from blockbuster comedies - once again popular cinema but without the markers of masculinity and femininity of clusters 1 and 3. Tastes in terms of reading show a preference for celebrity and television magazines, romance novels, and how-to-guides. This cultural world can be defined as that of the most widespread popular culture, focused on what is most materially and culturally most accessible (television, radio). We can also see a homology with the social properties associated with it. On the one hand, emerging popular tastes - should we say those that are "very now"? - but that are not markedly differentiated in gender terms, and on the other hand a cluster that is more working class than it is young (more than cluster 1, less than cluster 3 ) and less 
differentiated along gender lines, although it is slightly more feminine (which explains the significant role of romance novels and the rejection of Western films or Star Wars).

Beyond the variations in popular tastes linked to age and gender, and if we allow ourselves to push the analysis forward using hypotheses from outside the data set, we can see that between these three clusters there are different degrees of remoteness from cultural practices, which explains their relative positions on the $U$ of the legitimacy scale. We observe positions that are both very close and not very hierarchical, with "cluster 3" in the upper left-hand side of the graph, at the "top" of the scale, more masculine and juvenile with certain tastes connected to strategies importing popular cultural products within legitimate worlds (for example science fiction films like Matrix and certain kinds of pop music, rap or electronic music), then cluster 2 is less differentiated, and then "at the bottom" of the working class sphere, cluster 1 which is more feminine and older, with its romance novels or the film Titanic which appear to be the products that are the furthest away from legitimate culture. There therefore seemed to be three forms of cultural illegitimacy; in other words, there are three ways to disqualify based on a perspective of legitimate culture. Firstly, there is simple naivete and the invisibility of outdated and sentimental practices (cluster 1)how many university graduates are aware of the ongoing success of Mills and Boon romance novels? Then there is the distasteful vulgarity of large audience commercial products (cluster 2) which are either rejected or consumed in passing. Finally, there is the tyranny of the successive fashions imposed by the culture industry (cluster 3) from which snobbish consumers will be able to graze, or even contribute to the recognition of certain elements as young, masculine counter cultures. We can see that the PCF study of 2008 enables us to characterise popular tastes both in terms of their distance from legitimate culture and in terms of some of their "positive" foundations - practical accessibility of television and radio (in financial terms, presence in the everyday environment, or in terms of scheduling), and aesthetic accessibility of the most widespread products, those that are the most widely shared and appreciated. This "positive" characterisation is of course minimalist and it overlooks many aesthetic practices - embroidery, tuning, tattoos, fashion and make up, interior decorating, etc. ${ }^{25}$ However, the available data allow us to establish the prescriptive power of the dominant culture - its legitimacy from one end of the social space to the other - and to suggest how this power operates alongside other popular practices. ${ }^{26}$

Cluster 4 (Appendix 1, Table 4) is characterised by high levels of consumption of music and cinema, and more moderate consumption of television and reading. Everything here suggests intermediary tastes drawing on both legitimate culture and popular culture, with a greater orientation towards legitimate culture through, in particular, the rejection of some more popular tastes (science-fiction and action films), but also an appreciation for arthouse films and some comedies that are sometimes watched and sometimes rejected. Television preferences here are focused on key programs on Canal ${ }^{27}$ (Guignols de l'info ${ }^{28}$, Prison Break, Desperate Housewives), as well as a few "bourgeois" programs (Arrêt sur images ${ }^{29}$, Strip-tease ${ }^{30}$ ). Music is primarily rock, but also hard rock or jazz, with the rejection of André Rieu as "vulgar" reading is primarily focused on graphic novels, including the "posh" Hugo Pratt, ${ }^{32}$ and includes a focus on crime novels, with diversions for how-to books, current affairs, and classical or historical novels - and the "academic" taste for Molière. To this description we must also add quite distinct qualifications in terms of masculine tastes (a rejection of romantic films and musical comedies, a taste for hard rock, and the sports program 
Stade 2) and emerging forms of culture (rock and electronic music, comics and graphic novels, Canal+ TV, etc.). In terms of social characteristics, this is also a pole that is marked by high levels of economic and cultural capital and by an overrepresentation of men and young adults. The interaction between these three properties, the first concerning legitimate culture and the two others more masculine and emergent cultures probably explains the "intermediary" nature of this sphere of tastes which concerns young adult men who are (very) highly educated. In other words, this is not so much a "middle-class" sphere, even though intermediate professions are also overrepresented here, as it is a sphere in which the "average" coherence is based on the juxtaposition of profiles that only share the fact that they are neither the "highest" nor the "lowest" and combine legitimate tastes, tastes that are being legitimised, and a few more vulgar tastes.

Cluster 6 (Appendix 1, Table 6) is characterised by an intense consumption of cinema, music and reading and low levels of television. It is associated with all categories of legitimate culture, including the rejection of popular tastes (blockbuster comedies and Titanic, international pop music, electronic music and rap, disinterest for television as a whole with the exception of more intellectual or cultured programs). We also observe some incursions of intermediary tastes such as crime novels or graphic novels, Star Wars, rock, or world music. In terms of social characteristics, this pole is associated with a high level of economic and cultural capital, being an adult or older, and low levels of gender differentiation.

Cluster 5 (Appendix 1, Table 5) is characterised by a taste for reading and music, less pronounced for cinema, and low levels of consumption of television. Tastes that are overrepresented here belong to dominant culture but are of a more established and classical nature than for cluster 6 . There are not many films that are appreciated, no rock, but rather classical music (the only category that is highly significant), opera and jazz, no trends toward graphic novels or crime novels. The social characteristics associated with this group also have a homologous variation - high levels of cultural and economic capital but slightly lower levels of education on average, ${ }^{33}$ an older population (concentration of over-50-year-olds) and a greater proportion of women.

Here we observe an established (or "classical") variant of legitimate culture, in which the "emerging" form (which is "becoming part of the canon") is represented by cluster 6. The border of legitimacy indeed runs just "under" these two clusters on the U-curve, and not "between" them as the first interpretation suggested, based on the identification of the legitimacy scale with the first axis. Moreover, the interpretation of the HAC confirms the benefit of studying the variables of social position that are the most correlated with the first two factors of the MFA together. Education, age, and gender "operate together" to define cultural legitimacy in social terms; each echelon corresponds to a different configuration of the homology between tastes and social space with a relative prevalence of one or other categories of social position or one or other categories of taste. The analysis also has the advantage of not constructing a hierarchy of the causal weight of these variables, and not playing them off against each other. In some studies, social class remains ultimately deterministic, whilst in others gender or (more often) age "dominates over" social class. Although education is indeed the most discriminating variable, and although we can see this as an indicator of causal weight, it remains imprecise, even more because, as we have seen, restricting ourselves to a single indicator leads to interpretations that are approximate or even incorrect. 
What is important is that education never has an impact independently of age and gender, and vice versa, if we limit ourselves to the pre-eminent variables chosen for the scale. It is therefore worth exploring the way they interact in more depth, in order to refine the characterisation of the social space that results in the scale of cultural legitimacy.

\subsection{Projecting Interactions onto the MFA: a Visualisation of the Interactions Between Education, Age, and Gender}

This new avenue is the most direct statistical response to the question we have posed. It projects the combinations of the categories of supplementary variables of social position within relations of social class (indicated by education), gender, and age,$^{34}$ onto the MFA of cultural tastes. In practical terms, the variables are combined in pairs firstly age and gender (Figure 5), then gender and education (Figure 6), and finally age and education (Figure 7). In each figure, we can see variations in the distance between the analogous categories for each variable. For example, in Figure 5, between women aged 15 to 24 and men aged 15 to 24 .

Fig. 5. Concomitant variations of age and gender on the MFA

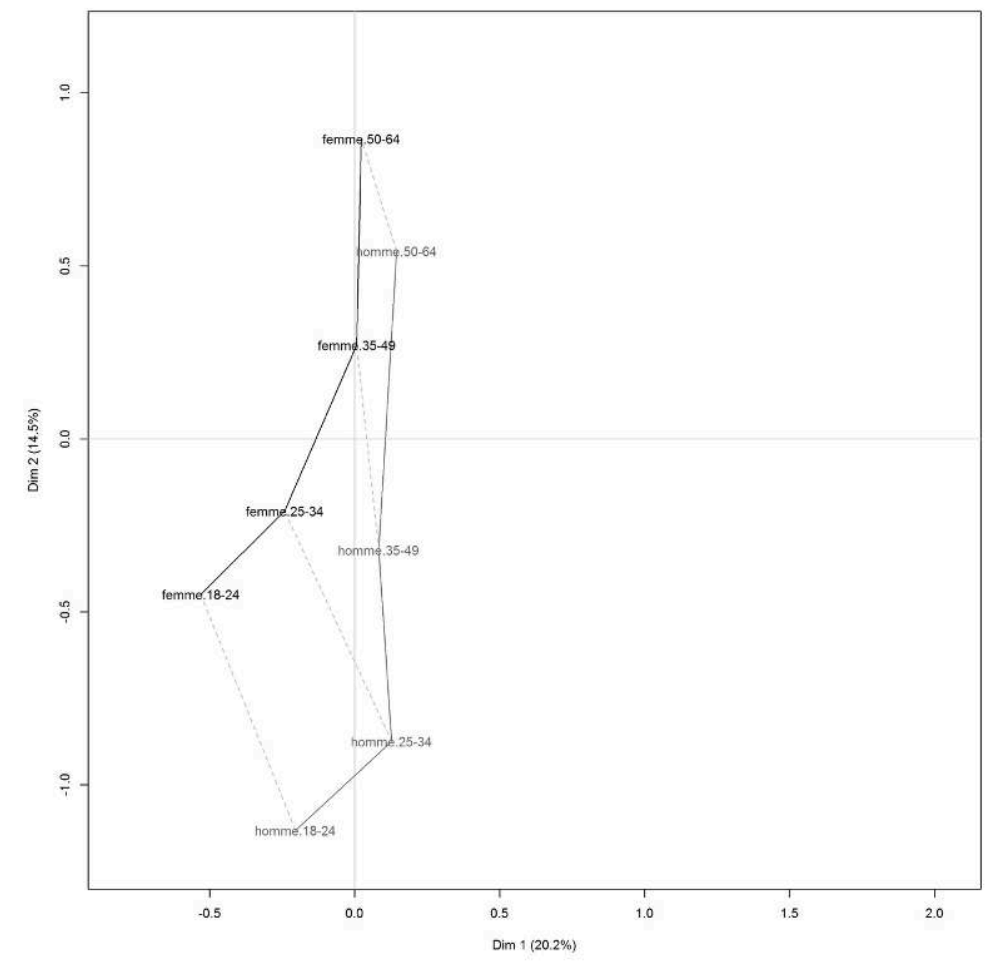

Source: Pratiques culturelles des Français 2008 (DEPS)

Logically, at any age (Figure 5), women often lean more towards established and feminised cultural practices, and this distinction from men is more accentuated among young people (there is above all a difference between the 50 to 64-year-olds and the others). Inversely, young people are more often drawn towards emerging and masculine practices and this distinction is more accentuated among men. In other words, getting older reduces the distinction between the genders and variations 
according to age are larger for men than for women; we observe the same connection between femininity and "established" practices and masculinity and "emerging" practices.

What is less expected is that the "male" categories are strictly aligned on axis 2 (Figure 5) while the "female" categories associated with younger age groups are (slightly) sensitive to variations in the distance from legitimate culture on this axis. For example, young women are both drawn to emerging and masculine tastes, although much less than their male counterparts, and also drawn to the most widespread popular tastes, which is much less the case for their male counterparts. Without being able to draw decisive conclusions here, it is probable that this difference is due to the fact that women subscribe less to the cultural practices measured here than men do. On the second axis we can see the correlation between legitimate tastes and the intensity of practices. We can also observe the hypotheses formulated (in regard to cluster 3) of an association between old-fashioned and sentimentalist tastes and the most intense cultural disqualification, so intense in fact that these popular established feminine spheres are almost invisible from the perspective of legitimate culture.

Fig. 6. Concomitant variations of gender and education

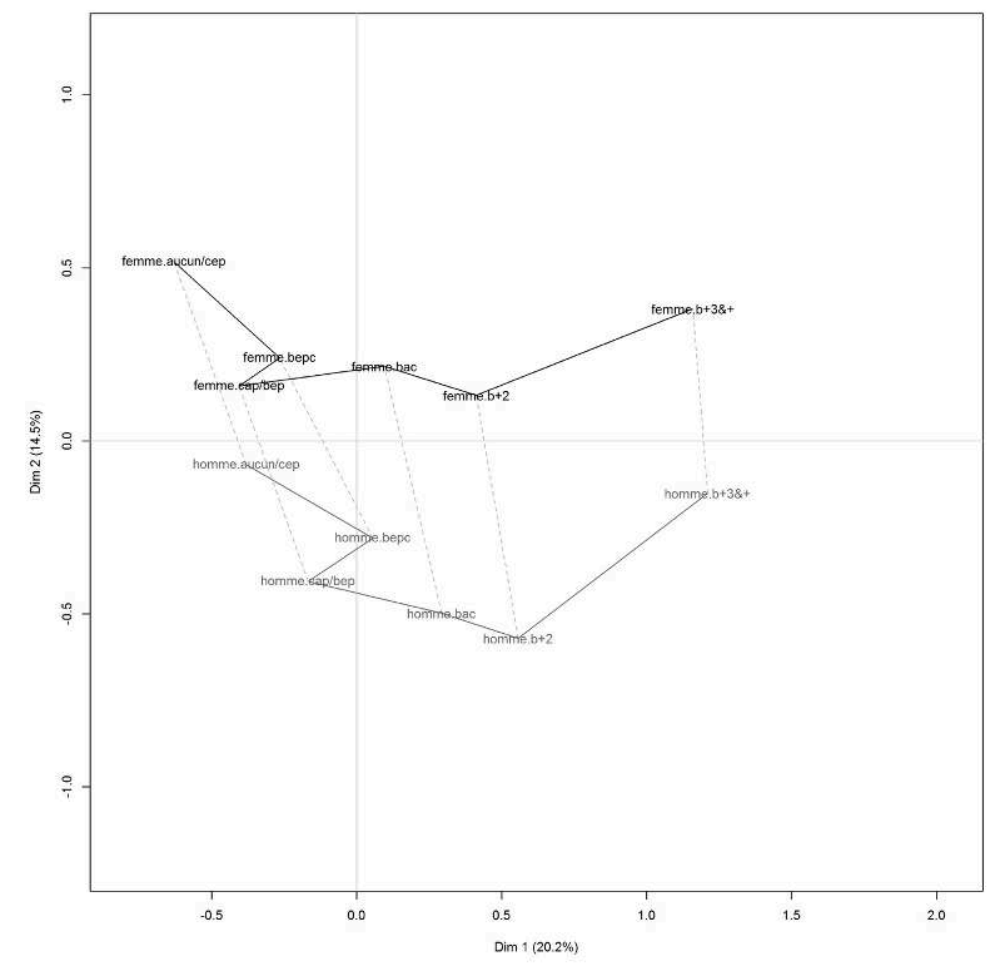

Source: Pratiques culturelles des Français 2008 (DEPS) education. For a given education level, men and women are at the same level on the first axis. The gap between men and women is the same on the second axis, women being systematically situated higher, i.e. tending towards established and feminine tastes.

We also observe the attraction of higher and lower levels of education towards the pole of established and feminine tastes..$^{35}$ Given this, we can hypothesise that on the one 
hand, those with higher levels of education are closer to the sphere of more legitimate culture which is associated with dominant classes (axis 1) but also with established and feminised culture (axis 2). On the other hand, those with the lowest levels of education are also associated with women and older individuals through a structural effect that combines the intensity of practice (these three categories are those with the lowest level of cultural practices) and maximum distance from established and feminised practices in regards to legitimate norms.

Fig. 7. Concomitant variations of age and education

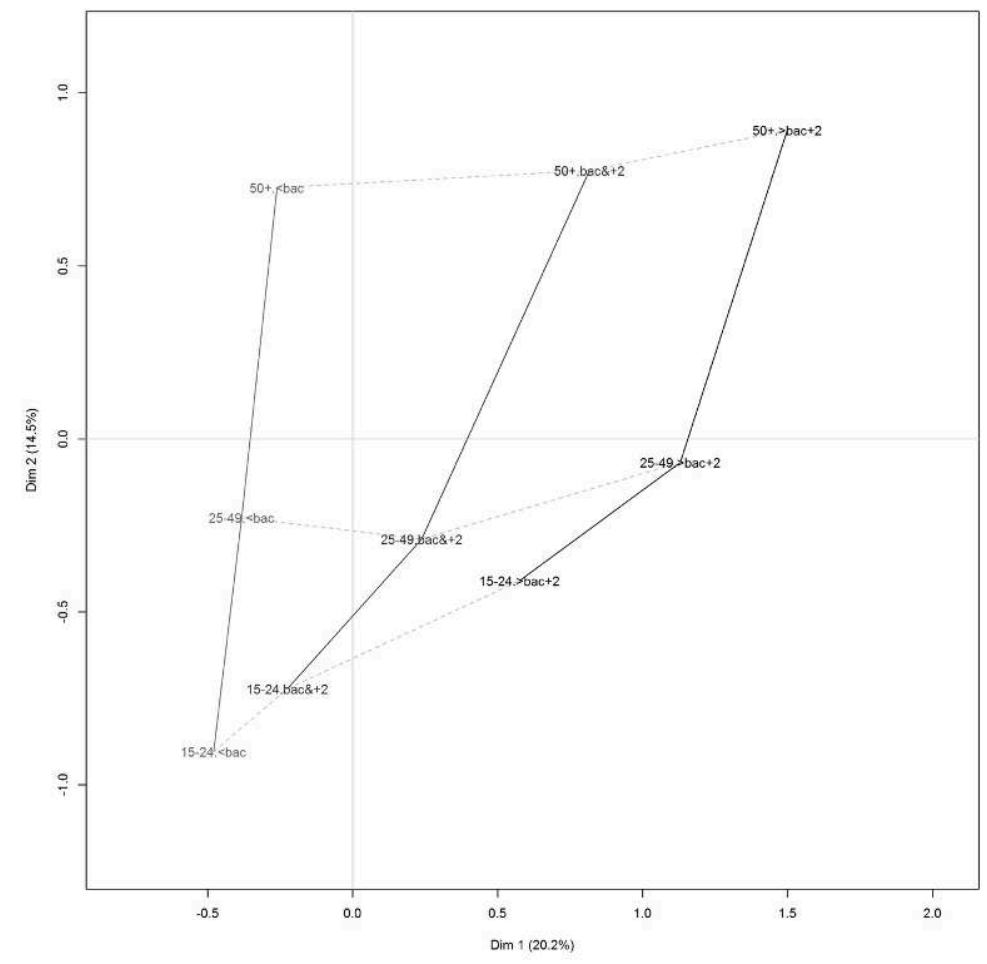

Source: Pratiques culturelles des Français 2008 (DEPS)

31 Figure 7 shows that the gap between different levels of education on the axis of distance from legitimate culture is accentuated with age. The difference is especially pronounced between the 15 to 24-year-olds and 25 to 49-year-olds; and the 15 to 24year-olds with more than two years post-secondary education shift onto the side of legitimate tastes. This suggests that the increase in different education levels with age is primarily linked to the fact that certain number of young people do not finish their studies. However, once again, the association of legitimate culture both with age and education is not invalidated here. Age has little effect for those without educational qualifications. But as soon as there is a minimum of educational qualifications, differences according to age increase significantly - and this is not only linked to the 15 to 25-year-old category (who are sometimes still studying), it is also verified for the 25 to 49 -year-olds and the 50-year-olds.

Moreover, on the second axis, for a given age if we increase the level of education, we move toward established and feminine tastes, particularly for the 15 to 24 year-old age group. Furthermore, on this same axis age leads to greater variation for those with less 
education. For the most highly educated, their position according to their age is both more homogenous, more established, and more feminine.

In light of previous interpretations, we can finalise our use of this tool for visualising interactions between variables by projecting the three variables together (education, age, and gender) onto Figure 8. The gap between men and women is larger for young people and those with lower education. Gender differentiation fades as we move up the legitimacy scale. At the same time, for a given age and education level, women have tastes that are lower on the scale, when they are toward the middle and lower part of the social space, and more legitimate when they are in the higher part. Here we can see the association between established tastes and feminine tastes and the association between the legitimacy scale and the interaction between gender, age, and education. The legitimate end of the U-curve is made up of women over-50 who have completed more than two years tertiary education. Among the most highly qualified, men between 25 and 49 are situated - along with the 15 to 24 year olds - in the "dip" of the $\mathrm{U}$, associated with emergent and less legitimate culture, whereas for women, 25 to 49 year olds are much closer to the more legitimate pole than 15 to 24 year olds.

Fig. 8. Projection of the combination of education, age, and gender onto the MFA of tastes

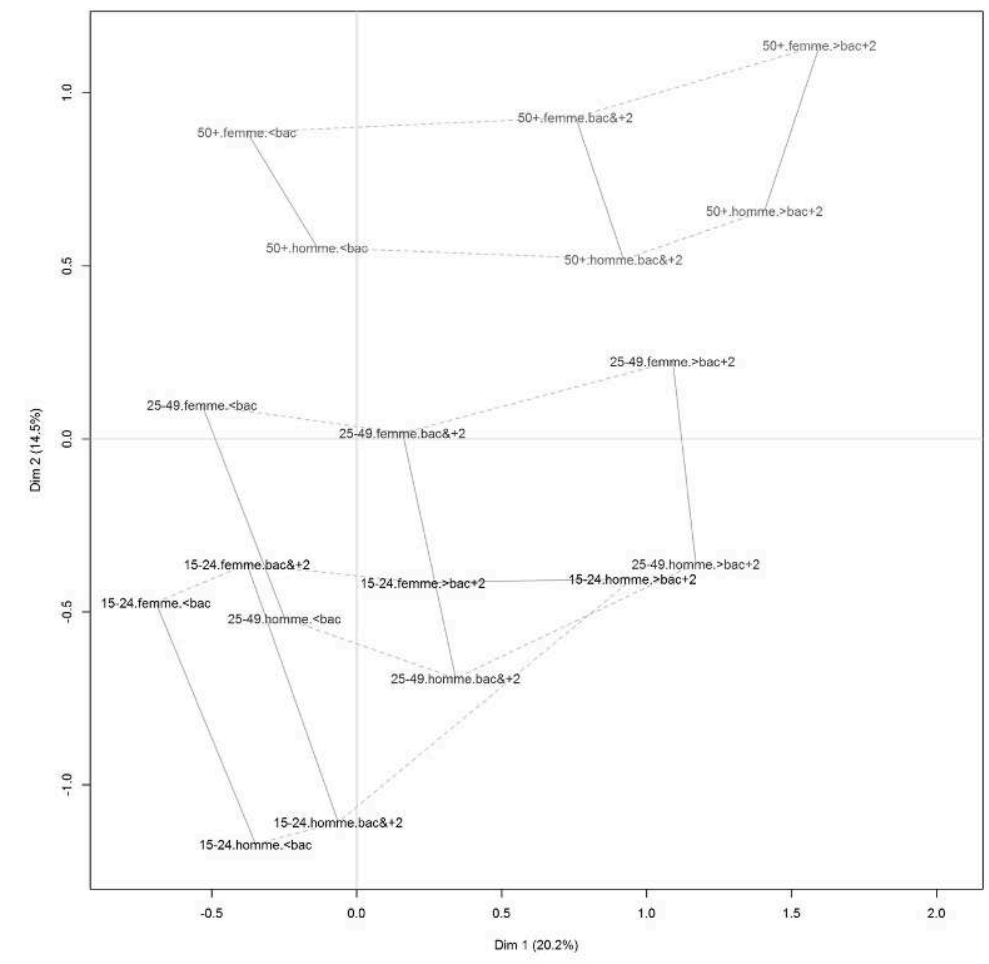

Source: Pratiques culturelles des Français 2008 (DEPS)

\section{Conclusion}

At the time this study was conducted (2008), legitimate culture was not simply the culture of the upper classes, it was also established, feminine, and bourgeois culture. And illegitimate culture was not merely popular culture, it was also established, feminine, and popular culture. Or perhaps that should be "the most illegitimate 
culture", because on the one hand it is distinct from mass culture, which is popular without being particularly associated to gender, or age groups, and on the other hand, it is distinct from the vulgarity of popular, juvenile, or masculine cultural forms or counter cultures which are closer to more legitimate spheres, perhaps because they are both more threatening and more intent on claiming legitimacy (in any case, it is this culture that the more highly educated consumers and cultural media draw on to renew their repertoires of tastes). Cultural legitimacy therefore exists simultaneously in all kinds of power relations - class, age, and gender. The legitimacy scale is constructed by non-linear interactions between these three types of power relation, to the extent that, for example, the "established and feminine" aspect is both more legitimate (classical music or poetry) and the most illegitimate (French pop music or romance novels).

It is highly likely that these interactions, studied here using data from 2008, may vary over time. For example, the association between legitimacy and established culture (classicism, heritage) only became dominant in the late $19^{\text {th }}$ century (see for example, for painting Moulin 1995; for music Weber 1975, and Fauquet \&Hennion 2000; for cinema in the 1960s Duval 2016 or Mary 2006), so the association between legitimacy and femininity may be relatively recent, connected to general trend towards the feminisation of cultural practices that has been observed in many studies since the 1980s (Donnat 2005; Albenga et al. 2014). This would allow us to reanalyse the gender division of cultural legitimacy in the $19^{\text {th }}$ century, between the "masculine" invention of serious scholarly classicism and the "feminine" tastes for more current cultivated pastimes associated with the link between "general culture", the education of "young ladies" and the transmission of culture by mothers (see for example Lenoir 1979 for the piano, and more generally Weber 1975). Indeed, to explain the interactions observed in 2008 it would be necessary to do a specific socio-historical study, exploring the transformations of cultural legitimacy based on the multidimensionality of the social relations that underlie it, in other words systematising the analysis in terms of interactions, rather than selecting the classist, ageist, or gendered dimensions of legitimacy. This would allow us to enrich and refine our understanding of cultural history.

Moreover, along with the statistical association between cultural legitimacy and dominant tastes among older bourgeois women, we can see an image of legitimate culture as it is seen by those who reject it: as snobbish, old-fashioned, and "for girls" (or possibly "for gays" when this is used as an insult based on sexuality to mean gender - see Détrez 2011; Octobre 2011). Inversely, for those who subscribe to it, legitimate culture appears as works that are highbrow, selected by posterity, and elegant. These images are perfectly in keeping with the logic of Distinction which associates the social properties of consumers and the public image of consumptions. The choice of adjectives is also uncomfortable given that most are drawn from the language of class, age, or gender relations (and other social power relations). Some provide language for others, without there being a decisive "order" in this respect; it varies according to the context. This is an additional indicator that cultural legitimacy, like social authority, is based on the constantly variable articulation of all social power relations. 


\section{BIBLIOGRAPHY}

ALBENGA Viviane, HATZIPETROU-ANDRONIKOU Reguina, MARRY Catherine, ROHARIK Ionela (2014).

"Pratiques musicales des amateurs à l'âge adulte: emprise ou déprise du genre?" In OCTOBRE Sylvie (ed.). Questions de genre, questions de culture. Paris, Ministère de la culture - DEPS: 101-124.

AVRIL Christelle (2014). Les Aides à domicile. Un autre monde populaire. Paris, La Dispute, coll. « Corps santé société ».

BARGEL Lucie (2009). Jeunes socialistes/ jeunes UMP. Lieux et processus de socialisation politique. Paris, Dalloz.

BAUdelot Christian, CARTIER Marie, Detrez Christine (1999). Et pourtant ils lisent... Paris, Seuil. BENNETT Tony, SAVAGE Mike, sILVA Elizabeth, WARDE Alan, GAYO-CAL Modesto, wrIGHT David (2009). Culture, Class, Distinction. London, Routledge.

BORGES PEREIRA Jose Virgilio (2005). Classes e Culturas de Classe das Famílias Portuenses. Classes sociais e "modalidades de estilização da vida" na cidade do Porto. Porto, Afrontamento/Instituto de Sociologia da Faculdade de Letras da Universidade do Porto.

BOURDIEU Pierre (1984) [1979]. Distinction: A Social Critique of the Judgement of Taste. English translation by Richard Nice. Cambridge, Harvard University Press.

BOURDIEU Pierre \& PASSERON Jean-Claude (1979) [1964]. The Inheritors: French students and their relations to culture. English translation by Richard Nice. Chicago, University of Chicago Press. CHRISTIN Angèle (2012). "Gender and Highbrow Cultural Participation in the United States." Poetics, 40(5): 423-443.

COULANGEON Philippe (2003). "Social Stratification of Musical Tastes: Questioning the Cultural Legitimacy Model." Revue française de sociologie, 44(1): 3-33.

COULANGEON Philippe (2011). Les Métamorphoses de la distinction. Inégalités culturelles dans la France d'aujourd'hui. Paris, Grasset.

CRENSHAW Kimberlé Williams (1994). "Mapping the Margins: Intersectionality, Identity Politics, and Violence against Women of Color." In ALBERTSON FINEMAN Martha \& MYKITIUK Rixanne (eds). The Public Nature of Private Violence. New York, Routledge: 93-118.

DETREZ Christine (2011). "Des Shonens pour les garçons, des shojos pour les filles? Apprendre son genre en lisant des mangas." Réseaux, 168-169: 165-186.

DONNAT Olivier (1994). De l'Exclusion à l'éclectisme. Les Français face à la culture. Paris, La Découverte. DONNAT Olivier (2005). "La Féminisation des pratiques culturelles." In MARUANI Margaret (ed.). Femmes, genre et sociétés. L'état des savoirs. Paris, La Découverte: 423-431.

DONNAT Olivier (2011). "Pratiques culturelles, 1973-2008. Dynamiques générationnelles et pesanteurs sociales." Culture études, 7: 1-36.

DORLIN Elsa (dir.) (2009). Sexe, race et classe. Pour une épistémologie de la domination. Paris, Presses universitaires de France.

DUVAL Julien (2011). "L'Offre et les goûts cinématographiques en France." Sociologie, 2(1): 1-18.

DUVAL Julien (2016). Le Cinéma au XXe siècle. Entre loi du marché et règles de l'art. Paris, CNRS éditions. 
ESCOFIER Brigitte \& PAGÈs Jérôme (2008). Analyses factorielles simples et multiples: objectifs, méthodes et interprétation. Paris, Dunod.

FABIANI Jean-Louis (2007). Après la culture légitime: objets, publics, autorités. Paris, L'Harmattan.

FAUQUET Joël-Marie \& HENNION Antoine (2000). La Grandeur de Bach: l'amour de la musique en France au XIX ${ }^{e}$ siècle. Paris, Fayard.

GLÉVAREC Hervé \& PINET Michel (2009). "La ‘Tablature' des goûts musicaux: un modèle de structuration des préférences et des jugements." Revue française de sociologie, 50(3): 599-640.

GRIGNON Claude \& PASSERON Jean-Claude (1989). Le Savant et le populaire. Misérabilisme et populisme en sociologie et en littérature. Paris, Gallimard/Seuil/EHESS.

JAUNAIT Alexandre \& CHAUVIN Sébastien (2012). "Représenter l'intersection. Les théories de l'intersectionnalité à l'épreuve des sciences sociales." Revue française de science politique, 62(1): $5-20$.

KHAN Shamus Rahman (2011). Privilege: The Making of an Adolescent Elite at St. Paul's School. Princeton, Princeton University Press.

LAHIRE Bernard (1993). La Raison des plus faibles. Rapport au travail, écritures domestiques et lectures en milieux populaires. Lille, Presses universitaires de Lille.

LAHIRE Bernard (2004). La Culture des individus. Dissonances culturelles et distinction de soi. Paris, La Découverte.

LENOIR Rémi (1979). "Note pour une histoire sociale du piano." Actes de la recherche en sciences sociales, 28: 79-82.

LE RENARD Amélie (2019). Le Privilège occidental. Travail, intimité et hiérarchies postcoloniales à Dubaï. Paris, Presses de Sciences Po.

LE ROUX Brigitte \& ROUANET Henry (2004). Geometric Data Analysis: From Correspondence Analysis to Structured Data Analysis. Dordrecht, Kluwer Academic Publishers.

MAIGRET Éric \& MACÉ Éric (2005). Penser les médiacultures. Paris, Armand Colin/INA.

MARY Philippe (2006). La Nouvelle vague et le cinéma d'auteur: socio-analyse d'une révolution artistique. Paris, Seuil.

MAUGER Gérard, POLIAK Claude, PUDAL Bernard (2010). Histoires de lecteurs. Paris, Éditions du Croquant.

MOULIN Raymonde (1995). De la valeur de l'art. Paris, Flammarion.

остоBRE Sylvie (2011). "Du féminin au masculin. Genre et trajectoires culturelles." Réseaux, 180: 102-124.

PASQUIER Dominique (2005). Cultures lycéennes. La tyrannie de la majorité. Paris, Éditions Autrement. PEDLER Emmanuel \& ETHIS Emmanuel (2001). "Le Choix des œuvres. Chassé-croisé des publics et des programmations au Festival d'Avignon." In FABIANI Jean-Louis (ed). Le Goût de l'enquête. Pour Jean-Claude Passeron. Paris, L'Harmattan: 183-198.

PETERSON Richard A. \& KERN Roger M. (1996). "Changing Highbrow Taste: From Snob to Omnivore." American Journal of Sociology, 61(5): 900-907. 
PETERSON Richard A. \& SIMKUS Alfred (1992). "How Musical Tastes Mark Occupational Status Groups." In LAMONT Michèle \& FOURNIER Marcel (eds.). Cultivating differences: Symbolic boundaries and the making of inequality. Chicago, University of Chicago Press: 152-181.

PRIEUR Annick, ROSENLUND Lennart, SKJOTT-LARSEN Jakob (2008). "Cultural capital today: a case study from Denmark." Poetics, 36(1): 45-71.

ROBETTE Nicolas \& ROUEFF Olivier (2014). « An Eclectic eclecticism: Methodological and theoretical issues about the quantification of cultural omnivorism. » Poetics, 47: 23-40.

ROBETTE Nicolas \& ROUEFF Olivier (2017). "L'Espace contemporain des goûts culturels. Homologies structurales entre domaines de pratiques et entre classes sociales." Sociologie, 8(4): 369-394.

ROOSE Henk, VAN EIJCK Koen, LIEVENS John (2012). "Culture of distinction or culture of openness? Using a social space approach to analyze the social structuring of lifestyles." Poetics, 40(6): 491-513.

ROSENLUND Lennart (2000). "Cultural change in Norway: cultural and economic dimensions." International Journal of Contemporary Sociology, 37(2): 245-275.

SAVAGE Mike \& GAYO-CAL Modesto (2011). "Unravelling the omnivore: a field analysis of contemporary musical taste in the United Kingdom." Poetics, 39(5): 337-35.

SERRE Delphine (2012). "Le Capital culturel dans tous ses états." Actes de la recherche en sciences sociales, 191-192: 4-13.

SIBLOT Yasmine, CARTIER Marie, COUTANT Isabelle, MASCLET Olivier, RENAHY Nicolas (2015). Sociologie des classes populaires. Paris, Armand Colin.

SKEGGS Beverley (1997). Formations of Class and Gender: Becoming Respectable. London, Sage.

WEBER Max (1978). Economy and society: an outline of interpretive sociology. English translation by Ephraim Fischoff et al. Berkeley, University of California Press.

WEBER William (1975). Music and the Middle Class. The Social Structure of Concert Life in London, Paris, And Vienna (1815-1848). London \& Canberra / New York, Croom Helms / Holmes \& Meyer.

\section{APPENDIXES}

\section{Appendix 1. Description of the Six Clusters in the Typology of Cultural Tastes}

The tables indicate in bold type the categories in which the Pearson's residual is above 10 , in non-bold the categories in which the residual is between 5 and 10, and in italics the categories in which the residual is between 1.96 and 5. The categories are crossed out when it is their absence that is overrepresented. 
Table 1. Significant categories associated with cluster 1

\begin{tabular}{|c|c|}
\hline Cinema & $\begin{array}{l}\text { Likes: Titanic, Lord of the Rings, Star Wars, Pirates of the Caribbean, Matrix, Shrek } \\
\text { Has seen: Star Wars, Matrix, Shrek, Pirates of the Caribbean, Lord of the Rings, Les } \\
\text { Favourite genre : romance, } \\
\text { Genre never watched : science fiction, horror, } \\
\text { Frequency: never } \\
\text { Doesn't like: Star Wars, Lord of the Rings, Shrek, Brice de Nice, Pirates of the Caribbean, } \\
\text { Matrix, none }\end{array}$ \\
\hline Music & $\begin{array}{l}\text { Often listens to: rock, international variet., jazz, electro, classical, rap, french pop, hard } \\
\text { Never listens to: rock, rap } \\
\text { Favourite genre : French pop world } \\
\text { Listens daily: no } \\
\text { Live shows : rock, jazz, elassique, opéra, } \\
\text { Doesn't know : Rieu, Boulez } \\
\text { Likes: Rieu }\end{array}$ \\
\hline Television & 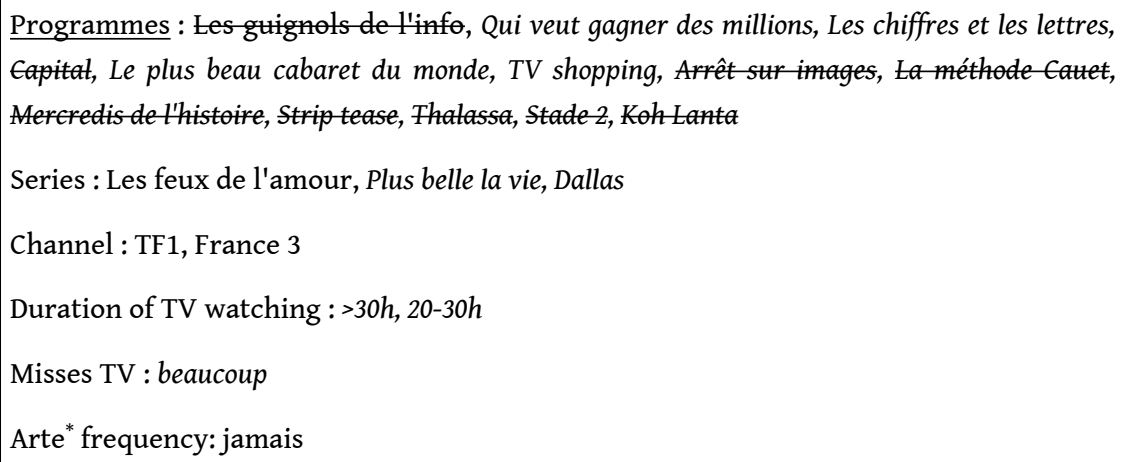 \\
\hline Books & $\begin{array}{l}\text { Author: King } \\
\text { Genres read : BD, Mills and Boon/romance, crime fiction, historical non-fiction, scientific non- } \\
\text { fiction, classical, art, dictionaries, politics, personal development, pratical non fiction } \\
\text { Number of books read : none } \\
\text { Magazines : TV, celebrity } \\
\text { Doesn't know : Molière, Pratt, Boulez, Char } \\
\text { Doesn't like : Molière } \\
\text { Newspaper reading: daily, regional }\end{array}$ \\
\hline
\end{tabular}




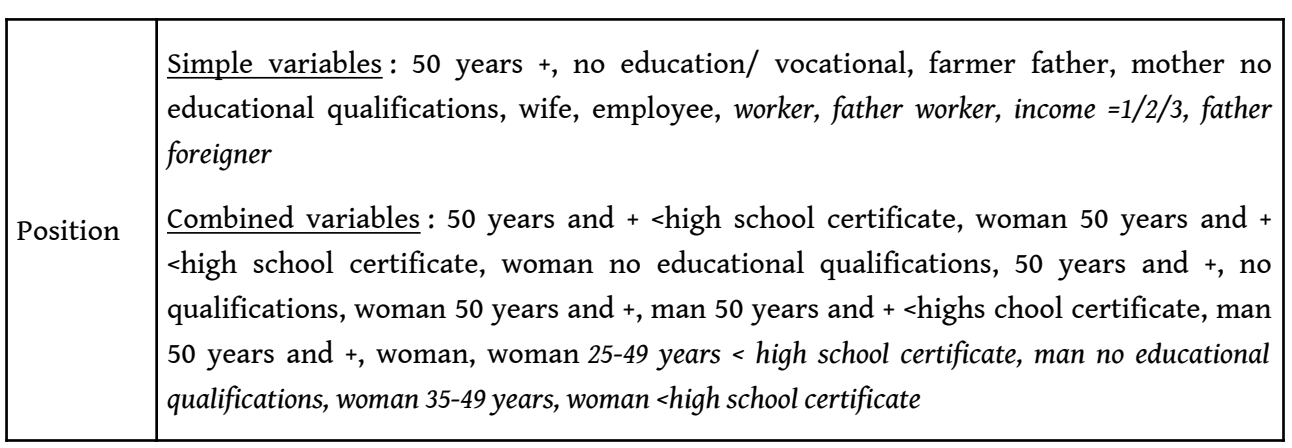

Source: PCF 2008 (DEPS). The full titles of the questions and response categories can be found at https://sociologie.revues.org/3275 (Appendix 1 of (Robette \& Roueff 2017)). * The Franco-German TV channel Arte is used as an indicator of high culture in television as it promotes cultural and intellectual programmes, and is free of advertising

Table 2. Significant categories associated with cluster 2

\begin{tabular}{|c|c|}
\hline Cinema & $\begin{array}{l}\text { Likes : Camping, Les bronzés, Titanic, Star Wars, Les visiteurs, Asterix } \\
\text { Has seen: Brice de Nice, La vie des autres, Shrek, Pirates des Caraibes, Asterix, Brokeback } \\
\text { Mountain, Camping } \\
\text { Prefered genre: comedy, action } \\
\text { Genre never watched: western } \\
\text { Frequency: 1-2,jamais } \\
\text { Doesn't like: Star Wars }\end{array}$ \\
\hline Music & $\begin{array}{l}\text { Often listens to: International pop, classical, jazz, rock } \\
\text { Has never listened to : Opera, classical, jazz, } \\
\text { favourite genre: international pop, French pop } \\
\text { live shows: elassical, jazz, rock, opera } \\
\text { Listens to music alone: never } \\
\text { does not know: Boulez }\end{array}$ \\
\hline Television & $\begin{array}{l}\text { Programs: Les enfants de la TV, Super Nanny, La méthode Cauet, Koh Lanta, La nouvelle } \\
\text { star, Qui veut gagner des millions, TV shopping, ça se discute, Aercedis de l'histoire, Arrêt sur } \\
\text { Channel: TF1, M6 } \\
\text { TV on: quotidiennement } \\
\text { duration of TV watching: }>30 \mathrm{~h} \\
\text { frequency of TV : everyday } \\
\text { Misses TV : a lot } \\
\text { watches Arte : never, rare }\end{array}$ \\
\hline
\end{tabular}




\begin{tabular}{|c|c|}
\hline Books & $\begin{array}{l}\text { Preferred genre: practical non-fiction } \\
\text { genres read: histont } \\
\text { number of books read: none } \\
\text { magazines: celebrity, none, TV } \\
\text { does not know: Pratt, Molière, Char } \\
\text { does not like: Molière } \\
\text { newspaper: never }\end{array}$ \\
\hline Position & $\begin{array}{l}\text { Simple variables: father worker, vocational, 25-34 years, worker, income }=2 \text {, mother with no } \\
\text { educational qualifications, 15-24 years, employee, no holiday home, private } \\
\text { combined variables: } 25-49 \text { years <high school certificate, woman 25-49 years <high } \\
\text { school certificate, woman 25-34 years, woman <high school certificate, woman 15-24 } \\
\text { years, woman 15-24 years <high school certificate, <high school certificate, man 25-49 years } \\
\text { <high school certificate, 25-34 years, 15-24 years <high school certificate, 15-24 years, man no } \\
\text { educational qualifications }\end{array}$ \\
\hline
\end{tabular}

Source: PCF 2008 (DEPS). The full titles of the questions and response categories can be found at https://sociologie.revues.org/3275 (Appendix 1 of [Robette \& Roueff 2017])

Table 3. Significant categories associated with cluster 3

\begin{tabular}{|l|l|}
\hline Cinema & $\begin{array}{l}\text { Likes: Pirates of the Caribbean, Matrix, Star Wars, Lord of the rings, Asterix, Shrek, Les } \\
\text { visiteurs, Camping, Les Bronzés } \\
\text { has seen: Matrix, Brice de Nice, Star Wars, Pirates of the Caribbean, Shrek, Lord of the } \\
\text { rings, Camping, Asterix, Brokeback Mountain, Les visiteurs } \\
\text { preferred genre: action, science-fiction } \\
\text { genre never watched: musical comedy, other, horror, romance } \\
\text { frequency: 5-11/year } \\
\text { does not like: none, Star Wars }\end{array}$ \\
\hline Music & $\begin{array}{l}\text { Often listens to : rap, electro, international pop., hard, rock, classical, French pop., jazz } \\
\text { has never listened to: classical, opera, jazz, rap, hard, electro } \\
\text { preferred genre: electro, rap, international pop, rock } \\
\text { listens everyday: yes } \\
\text { live shows: rave, elassical, jazz, } \\
\text { listens on: computer } \\
\text { listens alone: often } \\
\text { listens where: outside } \\
\text { does not know: Boulez }\end{array}$ \\
\hline
\end{tabular}




\begin{tabular}{|c|c|}
\hline Television & $\begin{array}{l}\text { Programs: La méthode Cauet, Koh Lanta, Les enfants de la TV, La nouvelle star, Stade 2, } \\
\text { Guignols de l'info, pas Thalassa, Qui veut gagner des millions, Super Nanny, Capital, Mercedis } \\
\text { de l'histoire, Vie privée vie publique } \\
\text { series: Prison Break } \\
\text { Channel: M6 } \\
\text { TV on : everyday } \\
\text { duration of TV watching : } 20-30 \mathrm{~h} \\
\text { Mrs TV : a lot, quite a lot } \\
\text { with whom: depends on the moment of the day } \\
\text { watches Arte : rarely, never }\end{array}$ \\
\hline Books & $\begin{array}{l}\text { Preferred genre: graphic novels } \\
\text { authors: Zep, Goscinny, King } \\
\text { Genres lus : histoire, BD, elassique, } \\
\text { number of books read: aucun, }<5 \\
\text { magazines: none } \\
\text { does not know: Pratt, Char } \\
\text { does not like: Molière } \\
\text { Newspaper: never }\end{array}$ \\
\hline Position & $\begin{array}{l}\text { Simple variables: 15-24 years, } 25-34 \text { years, man, worker, vocational, mother vocational } \\
\text { combined variables: man 15-24 years, man 15-24 years <high school certificate, 15-24 } \\
\text { years, man 25-34 years, 15-24 years <high school certificate, man 25-49 years <high } \\
\text { school certificate, man <high school certificate, } 25-34 \text { years, man, 25-49 years <high } \\
\text { school certificate, man 15-24 years high school certificate/ +2 postsecondary, 15-24 years high } \\
\text { school certificate/ +2 postsecondary, man 25-49 years high school certificate/ +2 postsecondary, } \\
\text { man high school certificate, man no education qualifications, man 35-49 years. }\end{array}$ \\
\hline
\end{tabular}

Source: PCF 2008 (DEPS). The full titles of the questions and response categories can be found at https://sociologie.revues.org/3275 (Appendix 1 of [Robette \& Roueff 2017])

Table 4. Significant categories associated with cluster 4

\begin{tabular}{|l|l|}
\hline Cinema & $\begin{array}{l}\text { Likes: Star Wars, Matrix, Lord of the rings, Shrek, Titanic, Pirates of the Caribbean, La vie } \\
\text { des autres, Brokeback Mountain } \\
\text { has seen: Matrix, Brokeback Mountain, Star Wars, La vie des autres, Pirates of the } \\
\text { Caribbean, Shrek, Brice de Nice, Lord of the rings, Astérix, Camping, Les visiteurs } \\
\text { favourite genre : science-fiction } \\
\text { genre never watched: musical comedy, romance, other, sencefiction } \\
\text { frequency: >12, 5-11, 6-10 } \\
\text { does not like: Titanic, Star Camping, Brice de Nice }\end{array}$ \\
\hline
\end{tabular}




\begin{tabular}{|c|c|}
\hline Music & $\begin{array}{l}\text { Often listens to: rock, hard, jazz, electro, } \\
\text { has never listened to: classical } \\
\text { favourite genre: rock } \\
\text { listens everyday: yes } \\
\text { live shows: rock, jazz, rave, classical, opera, pop } \\
\text { listens on: computer, CD } \\
\text { listens alone: often, everyday, rare } \\
\text { listens where: home, outside } \\
\text { does not like: Rieu }\end{array}$ \\
\hline Television & $\begin{array}{l}\text { Program: Guignols de l'info, Arrêt sur images, Strip tease, Mercredis de l'histoire, Qui } \\
\text { series: Prison Break, Desperate Housewives } \\
\text { Channel: Canal+, none } \\
\text { duration of TV watching : }<10 \mathrm{~h}, 10-15 \mathrm{~h} \\
\text { frequency of TV watching: } 3-4 \text { /week } \\
\text { misses TV : no, not much } \\
\text { watches Arte : every week, every month, everyday }\end{array}$ \\
\hline Books & $\begin{array}{l}\text { Favourite genre: crime fiction, graphic novels, other novels } \\
\text { author: King, Rowling, Goscinny, Nothomb } \\
\text { Genres read: graphic novels, science, crime novels, history, dictionaries, classical, } \\
\text { practical, political, art, historical novels, current affairs, personal development } \\
\text { number of books read: 11-20, >20 } \\
\text { knows: Pratt } \\
\text { likes: Molière } \\
\text { Newspaper: Le Parisien }\end{array}$ \\
\hline Position & $\begin{array}{l}\text { Variables: }>=+3 \text { postsecondary, income }=5 \text {, by the manager, }+2 \text { postsecondary, man, } \\
\text { manager, mother }+2 \text { postsecondary, intermediary professions, } 25-34 \text { years, holiday house, father } \\
\text { into memory profession, mother high school certificate, mother CAP/BEP, title certificate, public } \\
\text { combined variables: man } 25-49 \text { years }>+2 \text { postsecondary, man }>+2 \text { postsecondary, } 25-49 \\
\text { years }>+2 \text { postsecondary, man } 25-49 \text { years high school certificate } /+2 \text { postsecondary, } \\
\text { man } 25-34 \text { years, }>+2 \text { postsecondary, } 25-49 \text { years high school certificate/ }+2 \\
\text { postsecondary, }+2 \text { postsecondary, man, man } 35-49 \text { years, } 25-34 \text { years, man high school } \\
\text { certificate, high school certificate, } 15-24 \text { years }>+2 \text { postsecondary, woman } 25-49 \text { years. It } /+2 \\
\text { postsecondary, woman } 25-49 \text { years }>+2 \text { postsecondary, man } 15-24 \text { years }>+2 \text { high school } \\
\text { certificate }\end{array}$ \\
\hline
\end{tabular}

Source: PCF 2008 (DEPS). The full titles of the questions and response categories can be found at https://sociologie.revues.org/3275 (Appendix 1 of [Robette \& Roueff 2017]) 
Table 5. Significant categories associated with cluster 5

\begin{tabular}{|c|c|}
\hline Cinema & $\begin{array}{l}\text { Likes: none, Les bronzés, Lord of the rings, Pirates of the Caribbean, Star Wars, Matrix, } \\
\text { has seen: Brice de Nice, Pirates of the Caribbean, Matrix, Shrek, Asterix, Lord of the rings, } \\
\text { Titanic, Camping, Les bronzés, Star Wars, } \\
\text { favourite genre: historical, documentary, other, dramatic comedy, comedy } \\
\text { genre never watched: horror, Action, science fiction } \\
\text { frequency: 5-11 } \\
\text { does not like: Matrix, Les bronzés, Les visiteurs, Shrek }\end{array}$ \\
\hline Music & $\begin{array}{l}\text { Often listens to: classical, jazz, international pop, world, opera, electro, rap } \\
\text { never listens to: opera, rap, electro, elassical, hard, jazz, } \\
\text { favourite genre: classical, jazz, world } \\
\text { live shows: classical, opera, jazz, pop } \\
\text { listens on: radio } \\
\text { likes: Boulez, Rieu } \\
\text { does not like: Boulez }\end{array}$ \\
\hline Television & $\begin{array}{l}\text { Programs: Mercredis de l'histoire, } \\
\text { Arrêt sur images } \\
\text { series: Dallas } \\
\text { channels: France 2, France 3, France 5, Arte } \\
\text { TV on: never, rare } \\
\text { frequency of TV watching: 1-2 / per week, rare/never } \\
\text { duration of TV: <10h } \\
\text { Miss TV: no } \\
\text { watch Arte: every week, everyday }\end{array}$ \\
\hline Books & $\begin{array}{l}\text { Favorite genre: history, other novel } \\
\text { author: d'Ormesson } \\
\text { genres read: art, history, personal development, contemporary, political, classical, } \\
\text { dictionary, historical novels, current affairs, poetry, science, biography, practical } \\
\text { number of books read:>20, 6-10, 11-20 } \\
\text { Magazine: current affairs, fashion, none, } \\
\text { knows: Char } \\
\text { likes: Molière }\end{array}$ \\
\hline
\end{tabular}




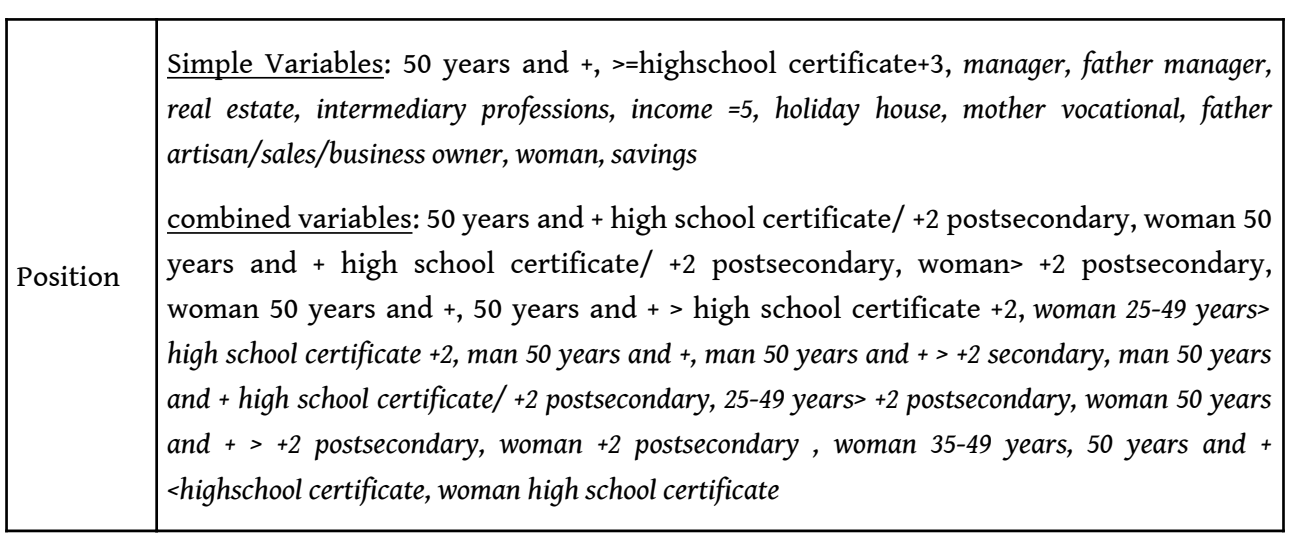

Source: PCF 2008 (DEPS). The full titles of the questions and response categories can be found at https://sociologie.revues.org/3275 (Appendix 1 of [Robette \& Roueff 2017])

Table 6. Significant categories associated with cluster 6

\begin{tabular}{|l|l|}
\hline Cinema & $\begin{array}{l}\text { likes : La vie des autres, Brokeback Mountain, Fitanic, Les bronzés, aucun, Camping, tes } \\
\text { visiteurs } \\
\text { has seen : La vie des autres, Brokeback Mountain, Camping, Titanic, Star Wars, Brice de } \\
\text { Nice, Les bronzés, Astérix } \\
\text { favourite genres : other, dramatic comedy, history, action, comedy, documentary } \\
\text { genre never watched : horror } \\
\text { frequency : >12 } \\
\text { doesn't like : Camping, Les bronzés, Brice de Nice, Les visiteurs, Pirates des Caraibes, } \\
\text { Titanic, Star Wars }\end{array}$ \\
\hline Music & $\begin{array}{l}\text { Never listen to : opera, international pop, classicat, jazz, electro, rap } \\
\text { Favourite genre : classical, jazz, rock } \\
\text { Listen everyday : yes } \\
\text { Live shows : classical, jazz, opera, rock, pop } \\
\text { Listen on : computer } \\
\text { Listens alone : often, everyday } \\
\text { Listen where : at home, outside } \\
\text { likes : Boulez } \\
\text { dos not like: Boulez, Rieu }\end{array}$ \\
\hline
\end{tabular}




\begin{tabular}{|c|c|}
\hline Television & $\begin{array}{l}\text { programme : Arrêt sur images, Mercredis de l'histoire, Strip tease, Ce soir, Qui-veut } \\
\text { gagner des millions, tes enfants de la TV, ta méthode Cautet, super Nanny, Koh Lantet, ça } \\
\text { se discute, Thalassa, Les guignols de l'info, Capital, ta nouvelle star, te plus grand cabaret du } \\
\text { monde, Stade } 2 \\
\text { series : Desperate housewives } \\
\text { channel : Arte, France 5, France } 2 \\
\text { TV on: never, rare } \\
\text { Frequency of TV watching: rare/never, 3-4 /week, 1-2/week } \\
\text { Duration of TV watching : }<10 \mathrm{~h}, 10-15 \mathrm{~h} \\
\text { miss TV : no, not much } \\
\text { watches Arte : everyday, every week }\end{array}$ \\
\hline Books & $\begin{array}{l}\text { Favourite genre : other novels, history } \\
\text { author : Nothomb, d'Ormesson, Goscinny } \\
\text { genres read : classical, politics, art, poetry, contemporary, history, dictionary, } \\
\text { development, science, historic fiction, graphic novels, current affairs, crime novels } \\
\text { number of books read : >20, 11-20 } \\
\text { magazines : current affairs, not TV } \\
\text { knows : Pratt, Char } \\
\text { likes : Molière } \\
\text { newspaper : Le Monde, everyday, Le Parisien }\end{array}$ \\
\hline Position & $\begin{array}{l}\text { simple variables : >= }+3 \text { postsecondary, manager, mother }+2 \text { postsecondary, manager } \\
\text { father, mother high school certificate, income }=5 \text {, savings, independent, holiday house, } \\
\text { real estate, public, } 50 \text { years and }+ \text {, intermediary profession, }+2 \text { postsecondary, father artisan/ } \\
\text { sales/business owner, income }=4 \\
\text { combined variables: }>+2 \text { postsecondary, } 50 \text { years and }+>+2 \text { postsecondary, woman }>+2 \\
\text { postsecondary, } 25-49 \text { years }>+2 \text { postsecondary, man }>+2 \text { postsecondary, woman } 50 \text { years } \\
\text { and }+>+2 \text { postsecondary, woman } 25-49 \text { years }>+2 \text { postsecondary, man } 25-49 \text { years }>+2 \\
\text { postsecondary, man } 50 \text { years and }++2 \text { postsecondary, } 50 \text { years and }+ \text { high school } \\
\text { certificate / }+2 \text { postsecondary, woman } 50 \text { years and }+ \text { high school certificate/ }+2 \text { postsecondary, } \\
50 \text { years and }+ \text { man } 50 \text { years and }+ \text { highschool certificate/ }+2 \text { postsecondary, man } 50 \text { years and }+ \text {, } \\
+2 \text { post secondary, woman }+2 \text { postsecondary, woman } 50 \text { years and }+\end{array}$ \\
\hline
\end{tabular}

\section{Appendix 2. Measuring Interaction Effects Using Linear Regression}

In order to corroborate the role of interactions between education, gender, and age in structuring cultural tastes, this appendix takes a different approach, drawing on linear regression models. The coordinates of individuals on the first, and then the second, 
axes of the MFA are used as dependent variables for a series of nested linear regressions that progressively introduce education, gender, and age as independent variables, and their first and second order interactions. This approach is essentially redundant with those used in the body of the article; it is simply a different way of making the structure of the data studied visible in terms of interactions between variables using tools to measure variance. It therefore aims to provide an additional element of proof of these interaction effects, for those who prefer quantification through linear regression models.

As in the previous analysis, to preserve sufficient population size, the age groups have been re-coded into three categories (under 25 years [<25ans]; 25-29 years[25-29ans]; 50 years and over [+50ans]), as has the level of education (less than high school certificate [ $<b a c]$; high school certificate and up to two years postsecondary[bac\&+2]; two years postsecondary and more [>bac+2]).

Models $1 \mathrm{~A}, 1 \mathrm{~B}$ and $1 \mathrm{C}$ estimate the overall effects of education, gender, and age on the position on the first axis of the M FA (Table 7). These effects correspond to what we observe if we project these variables as supplementary variables onto the MFA space. We can therefore see results we have already discussed: the level of education has a positive effect on the position on axis one (very pronounced for higher levels of education); being a woman has a negative but quite weak effect; age has a positive effect.

Model 1D estimates the partial effects of the three independent variables (education, age, gender). These partial effects are close to the overall effects observed in the previous models. There are thus not many structural effects in the relationship between the three variables and the dependent variable (coordinates of the individuals on axis 1). There is a marginal effect in that we observe a slight increase in the effects of education, a decrease in the effect of age, and an increase in the effect of gender.

The model $1 \mathrm{E}$ introduces first-order interaction effects ${ }^{36}$, that is between the three independent variables taken in pairs. The main effects of education and age remain positive but clearly decrease. They seem to be partly "captured" by the interactions. Indeed, the interaction effects between education and age are positive, and stronger when age or education are higher.

However, the main effect of the fact of being a woman increases significantly, from $-0,86$ à $-1,75$. At the same time, the interactions show that being a highly educated woman (as opposed to a highly educated man), or an adult or older woman (as opposed to a younger man) has a positive effect, which is all the more positive when education or age are higher. The main effect of gender, all other things being considered equal (here age and education being held constant), pushes women to the side of less legitimate tastes, while interaction with education or age pushes them towards more legitimate tastes.

The final model, $1 \mathrm{~F}$, is the saturated model. It introduces second-degree interactions as well as first-degree interactions, i.e. between the three independent variables together. The direction of the main effects remains unchanged from the previous model, and the size of the effects is also roughly the same, except for the high levels of education which notably increase. Most of the first order interaction effects decrease and/or have their p-value increase to levels that prevent them being interpreted. It is therefore probable that the second order interaction effects "capture" part of the first-order 
interaction effects in the model 1E. However, we can see that the effect of having a high school certificate or two years postsecondary [bac \& +2$]$ along with the oldest age group $[+50 a n s]$ is positive and very strong (greater than 3 ) and that the combination of the same level of education with the 25 to 49 -year-olds [25-29ans] has a less strong positive impact (between 1 and 1.5) but which is stable. Among the second order interaction effects, two are particularly strong (and positive) - being a woman with more than two years postsecondary education [femme, bac +2 ], combined with being over 50 years old [+50ans] or less markedly, between 25 and 49 years old [25-29ans].

In conclusion, we can see firstly that education is indeed the most powerful variable in structuring the position of individuals on the first axis of the MFA. The primary effects of educational qualifications of more than two years postsecondary education is the strongest of all the effects observed in the saturated model, and education is present in all interactions where the effect is greater than 1 (in absolute values). Moreover we observe the existence of interaction effects between the three social relations that we have studied here: being a highly educated woman at least 25 years old (and even more for those over 50 years old) is decisive in guiding individuals toward the most legitimate cultural tastes

Table 7 - Linear regression for the position on axis 1 of the MFA, according to education, gender, and age

\begin{tabular}{|c|c|c|c|c|c|c|c|c|c|c|c|c|}
\hline & \multicolumn{2}{|c|}{ Model 1A } & \multicolumn{2}{|c|}{ Model 1B } & \multicolumn{2}{|c|}{ Model 1C } & \multicolumn{2}{|c|}{ Model 1D } & \multicolumn{2}{|c|}{ Model 1E } & \multicolumn{2}{|c|}{ Model 1F } \\
\hline & estim. & $\begin{array}{l}p- \\
\text { value }\end{array}$ & estim. & $\begin{array}{l}\mathrm{p}- \\
\text { value }\end{array}$ & estim. & $\begin{array}{l}\mathrm{p}- \\
\text { value }\end{array}$ & estim. & $\begin{array}{l}\mathrm{p}- \\
\text { value }\end{array}$ & estim. & $\begin{array}{l}p- \\
\text { value }\end{array}$ & estim. & $\begin{array}{l}p- \\
\text { value }\end{array}$ \\
\hline (Intercept) & -1.59 & 0 & 0.57 & 0 & -1.58 & 0 & -2.53 & 0 & -1.44 & 0 & -1.57 & 0 \\
\hline Education & & & & & & & & & & & & \\
\hline$(r e f=<b a c)$ & & & & & & & & & & & & \\
\hline bac\&+2 & 2.64 & 0 & & & & & 2.85 & 0 & 1.05 & 0.0315 & 1.16 & 0.0798 \\
\hline$>\mathrm{bac}+2$ & 6.52 & 0 & & & & & 6.6 & 0 & 3.99 & 0 & 5.66 & 0 \\
\hline Gender & & & & & & & & & & & & \\
\hline$\left(r e f=h o m m e^{1}\right)$ & & & & & & & & & & & & \\
\hline Femme $^{2}$ & & & -0.49 & 0.002 & & & -0.86 & 0 & -1.75 & 0 & -1.48 & 0.0052 \\
\hline Age & & & & & & & & & & & & \\
\hline$\left(r e f=<25 a n s^{3}\right)$ & & & & & & & & & & & & \\
\hline $25-49$ ans & & & & & 1.91 & 0 & 1.14 & 0 & 0.31 & 0.3744 & 0.44 & 0.2516 \\
\hline 50 ans $\&+$ & & & & & 2.63 & 0 & 2.44 & 0 & 0.71 & 0.0666 & 0.86 & 0.0432 \\
\hline Education: Gender & & & & & & & & & & & & \\
\hline
\end{tabular}




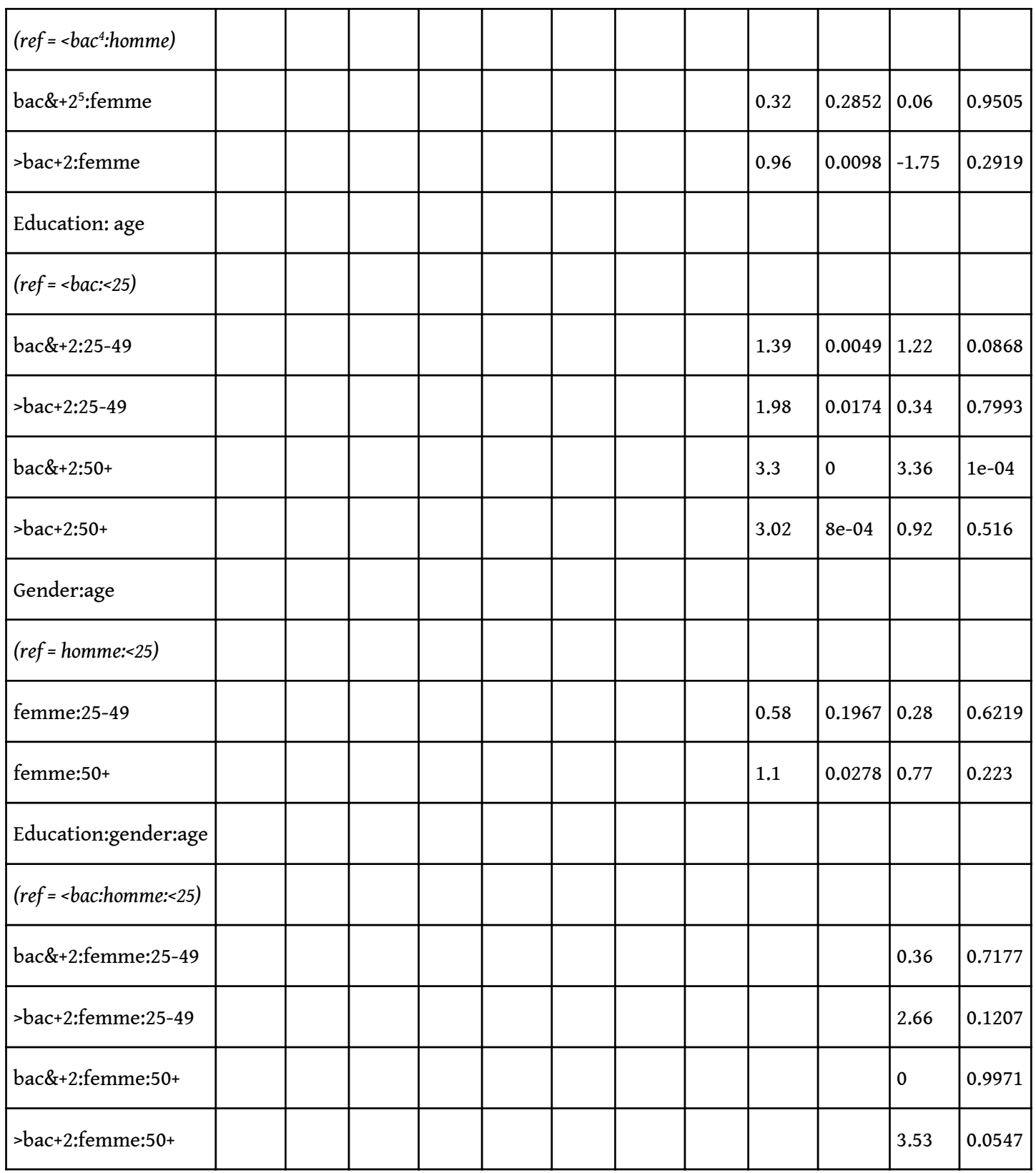

Source: PCF 2008 (DEPS). ${ }^{1}$ homme $=\operatorname{man}^{2}$ femme $=$ woman ${ }^{3}$ ans $=$ years ${ }^{4}$ bac $=$ high school certificate ${ }^{5}$ bac $+2=$ high school certification and up to two years post-secondary

Table 8 - Linear regression for the position on axis 2 of the MFA, according to education, gender, and age

\begin{tabular}{|l|l|l|l|l|l|l|l|l|l|l|l|l|}
\hline & \multicolumn{2}{|l|}{ Model 2A } & \multicolumn{2}{l|}{ Model 2B } & \multicolumn{2}{l|}{ Model 2C } & \multicolumn{2}{l|}{ Model 2D } & \multicolumn{2}{l|}{ Model 2E } & \multicolumn{2}{l|}{ Model 2F } \\
\hline & estim. & $\begin{array}{l}\text { p- } \\
\text { value }\end{array}$ & estim. & $\begin{array}{l}\text { p- } \\
\text { value }\end{array}$ & estim. & $\begin{array}{l}\text { p- } \\
\text { value }\end{array}$ & estim. & $\begin{array}{l}\text { p- } \\
\text { value }\end{array}$ & estim. & $\begin{array}{l}\text { p- } \\
\text { value }\end{array}$ & estim. & $\begin{array}{l}\text { p- } \\
\text { value }\end{array}$ \\
\hline (Intercept) & -0.18 & 0.0458 & -1.3 & 0 & -2.83 & 0 & -3.83 & 0 & -4.19 & 0 & -4.22 & 0 \\
\hline Education & & & & & & & & & & & & \\
\hline
\end{tabular}




\begin{tabular}{|c|c|c|c|c|c|c|c|c|c|c|c|c|}
\hline$(r e f=<b a c)$ & & & & & & & & & & & & \\
\hline $\mathrm{bac} / \mathrm{bac}+2$ & -0.28 & 0.0568 & & & & & -0.22 & 0.0825 & 0.21 & 0.6123 & 0.07 & 0.9051 \\
\hline$>\mathrm{bac}+2$ & 0.62 & $8 e-04$ & & & & & 0.6 & $1 e-04$ & 1.05 & 0.1381 & 2.36 & 0.0324 \\
\hline \multicolumn{13}{|l|}{ Gender } \\
\hline \multicolumn{13}{|l|}{$\left(r e f=h o m m e^{1}\right)$} \\
\hline Femme $^{2}$ & & & 2.12 & 0 & & & 2.08 & 0 & 2.4 & 0 & 2.47 & 0 \\
\hline \multicolumn{13}{|l|}{ Age } \\
\hline \multicolumn{13}{|l|}{$\left(r e f=<25 a n s^{3}\right)$} \\
\hline $25-49$ & & & & & 2.08 & 0 & 1.92 & 0 & 2.29 & 0 & 2.31 & 0 \\
\hline $50+$ & & & & & 5.52 & 0 & 5.36 & 0 & 6.04 & 0 & 6.1 & 0 \\
\hline \multicolumn{13}{|l|}{ education:gender } \\
\hline \multicolumn{13}{|l|}{$(r e f=<b a c:$ homme $)$} \\
\hline $\mathrm{bac} / \mathrm{bac}+2^{4}:$ femme & & & & & & & & & 0.23 & 0.3709 & 0.47 & 0.5482 \\
\hline$>\mathrm{bac}+2^{5}$ :femme & & & & & & & & & -0.01 & 0.9647 & -2.09 & 0.1358 \\
\hline \multicolumn{13}{|l|}{ Education:age } \\
\hline \multicolumn{13}{|l|}{$(r e f=<b a c:<25)$} \\
\hline $\mathrm{bac} / \mathrm{bac}+2: 25-49$ & & & & & & & & & -0.74 & 0.0782 & -0.58 & 0.3379 \\
\hline$>b a c+2: 25-49$ & & & & & & & & & -0.56 & 0.4269 & -1.86 & 0.1009 \\
\hline $\mathrm{bac} / \mathrm{bac}+2: 50+$ & & & & & & & & & -0.22 & 0.6417 & -0.04 & 0.9553 \\
\hline$>\mathrm{bac}+2: 50+$ & & & & & & & & & -0.26 & 0.7331 & -1.82 & 0.1303 \\
\hline \multicolumn{13}{|l|}{ Gender:age } \\
\hline \multicolumn{13}{|l|}{$(r e f=$ homme: $<25)$} \\
\hline femme:25-49 & & & & & & & & & -0.19 & 0.6186 & -0.25 & 0.6095 \\
\hline femme:50+ & & & & & & & & & -1.11 & 0.0087 & -1.24 & 0.02 \\
\hline \multicolumn{13}{|l|}{ Education:gender:age } \\
\hline \multicolumn{13}{|l|}{ (réf = <bac:homme:<25) } \\
\hline $\begin{array}{l}\text { bac/bac+2:femme: } \\
25-49\end{array}$ & & & & & & & & & & & -0.27 & 0.7447 \\
\hline
\end{tabular}




\begin{tabular}{|l|l|l|l|l|l|l|l|l|l|l|l|l|}
\hline >bac+2:femme:25-49 & & & & & & & & & & & 2.06 & 0.1549 \\
\hline bac/bac+2:femme:50+ & & & & & & & & & & & -0.29 & 0.7608 \\
\hline >bac+2:femme:50+ & & & & & & & & & & & 2.57 & 0.0988 \\
\hline
\end{tabular}

Source: Pratiques culturelles des Français 2008 (DEPS). ${ }^{7}$ homme $=\operatorname{man}^{2}$ femme $=$ woman $^{3}$ ans $=$ years ${ }^{4}$ bac $=$ high school certificate ${ }^{5}$ bac $+2=$ high school certification and up to two years post-secondary education

The second series of linear regressions models the position of individuals on the second axis according to education, gender, and age (Table 2). Models $2 \mathrm{~A}, 2 \mathrm{~B}$, and $2 \mathrm{C}$ reproduce the results of projecting the three explanatory variables as supplementary variables. Increasing age runs from down to up on the factorial plane as it has the strongest structuring power. Gender has an impact, being a woman is associated with a position in the top part of the space. Education is much less powerful here, and we once again observe the "U shape" in its categories: having more than two years postsecondary education is associated with a position on the positive side of axis 2 , whereas the intermediary level of education (high school certificate or high school certificate and two years postsecondary) is lower in the space than the lowest level of education (less than high school certificate).

In model 2D the coefficients are essentially the same as in previous models, indicating the weakness of structural effects between education, gender, and age in the second dimension of the factorial plane.

Introducing first-order interactions (model 2E) has relatively little impact on the main effects, accentuating them only slightly. The main interaction effect concerns women over 50: it is negative whereas the main effects of the "woman" and "over 50" categories are both positive. Secondly, we observe a slight negative interaction effect between intermediary categories of education and age ("high school certificate/+2 postsecondary" and "25-49 years").

The saturated model, i.e. with both first and second order interaction effects (model 2F), reveals a few changes compared to the previous model. Firstly, the positive effects of higher levels of education is clearly accentuated, moving from 1.05 to 2.36 . The other main effects remain essentially the same. Moreover, four first order interaction effects are now observable, and negative: interaction between being a woman and having a high level of education; between the fact of having a high level of education and being between 25 and 49 years old, or being over 50; between being a woman and being over 50. Like in the previous model, these notable interaction effects are inverse to the main effects of the categories concerned.

Finally, we observe two second-order interaction effects that are both positive and relatively strong. They characterise the fact of being a highly educated woman over 50, or secondarily a highly educated woman between 25 and 49 years old. In other words, like for axis 1 , the interaction between the fact of being a woman, being highly educated and being older "pushes" individuals toward more legitimate tastes, situated in the upper right-hand quadrant of the factorial plane.

These two series of linear regressions therefore confirm the hypotheses and results presented in the body of the article. The three social relations analysed here contribute 
to structuring cultural tastes. The three properties (being well educated, a woman, and older) have cumulative effects (main effects), but also combined effects (second-order interaction effects) to define legitimate cultural tastes, which correspond to what is cultivated, feminine, and established.

\section{NOTES}

1. The statistical study of the social distribution of cultural practices has for example been studied in Australia (Bennett et al. 1999), in Norway (Rosenlund 2000) in Portugal (Borges Pereira 2005), in Denmark (Prieur et al. 2008) and in Great Britain (Bennett et al. 2009).

2. Many studies have focused on musical tastes, particularly with the hypothesis of substituting the opposition between dominant omnivorism (appreciating several genres of different levels of cultural legitimacy) and popular univorism (appreciating only one illegitimate culture), for the opposition between bourgeois snobbism and popular vulgarity which is emphasised in Distinction. For a bibliography and more detail on this, including the reproduction of various methods of statistical constructions of legitimacy scales used by different authors, see Robette \& Roueff (2014).

3. This is the fifth round of a study that began in 1973 and was renewed in 1981, 1988, 1997-1998, 2008, and 2018-2019 (from which the data is not yet available at the time of writing). The sample from 2008 contains 5008 individuals that are representative of the French population aged over 15. For more information see the PCF website.

4. Elsewhere we have shown that the "rise in eclecticism" is above all a result of methodological and epistemological artefact. Moreover, it is not only empirically weak, but also entirely explained by the overall increase in omnibus cultural consumption (which concerns the majority of all social classes, such as for mainstream popular music) and by the diversification of cultural supply since the 1960s. Yet these two phenomena say nothing about the ways in which culture is consumed (Robette \& Roueff 2014). Everything leads us to think that with deepening socioeconomic inequality, specifically cultural symbolic violence (legitimacy) has also been accentuated, via the ways in which culture, including "objects" that appear to be shared, are consumed. We will therefore not discuss cultural omnivorism any further in this article.

5. On the identification of femininity to the stereotypes of bourgeois femininity, and masculinity with the stereotypes of working-class masculinity see Bargel 2009.

6. Each indicator is considered as one of the possible expressions of a taste or social position.

7. Data available through PROGEDO-ADISP (Production et gestion des données en sciences sociales-Archives de données issues de la statistique publique, Production and management of social science data - Archives of data from public statistics).

8. Supplementary variables are variables projected onto the factorial space but are not included in the calculations; they therefore do not contribute to the results.

9. The use of MFA consolidates the interpretation in terms of areas of taste but does not modify it much. The MCA of taste in terms of cinema, music, television, and reading present roughly the same structural axes, correlated to the same supplementary variables, and a similar cloud of points (individuals). These graphics are available from the authors upon request.

10. Although the analysis of this is presented in Roueff \& Robette 2017, it is worth noting here that we began by looking for other descriptions that did not have a connotation of position in social power relations, before testing their correlations. As is clear, for example, in the terms exo/esoteric, established/recent, heroic/romantic this attempt was fruitless if not naive. It is difficult to escape from the way culture is coded by social power relations; we will return to this in the conclusion. These descriptions 
can therefore be read as relatively realistic social judgements about the tastes of others within the relational logic of Distinction. Specifically, appreciating the poet René Char is considered as snobbish by individuals who do not appreciate him (and sometimes by those who do), action films are considered vulgar, macho and/or juvenile by those who do not like them (and sometimes by those who do), and so forth.

11. For the details of this process see Robette \& Roueff 2014, 2017.

12. Education accounts for $32 \%$ of the variance of the first axis, socio-professional category $16 \%$. Age explains $31 \%$ of the variance of the second axis, and gender $10 \%$. These values are obtained from the $\mathrm{R}^{2}$ value, from the linear regressions conducted with the coordinates of the axis as the dependent variable and the supplementary variable as the independent variable (see the indicator "eta"2" in Le Roux \& Rouanet 2014).

13. This $U$ shape could be seen as suggesting a Guttman effect. However, neither the cloud of individuals, nor of active variables (see Figure 2) present this form. The individuals and the active variables are all dispersed over a large portion of the space made by the two first axes. It is specifically the variables linked to the volume of capital (education, and to a lesser extent, socioprofessional category) that take this U-shape. Moreover, this same U can be seen on the MCA combining the four areas of taste (cinema, reading, music, television) as well as the MCA for each of these tastes (graphics available upon request). This confirms that it is not a statistical artefact resulting from the use of multiple factor analysis.

14. Generally, snobbish or posh tastes (esoteric or intellectual; associated with dominant classes, particularly the most highly educated), are opposed to vulgar or common tastes (exoteric, popular or "easy access"; associated with the working classes). From the same perspective, longestablished cultural tastes (which appeared in previous periods, prior states of the cultural field, but which are still consumed today; associated with older consumers) are often opposed to newer, recent or emerging cultural tastes (which may date to earlier periods, like graphic novels or comics which first appeared in the $19^{\text {th }}$ century, but which have become more visible as a genre in recent times - 1960s for comics - and are now associated with younger consumers). Finally, masculine tastes (expressing values socially considered masculine, associated with male consumers) are generally opposed to feminine tastes (expressing values that are socially considered as feminine, associated with female consumers). These descriptions, which are necessarily simplistic and relative, only appear tautological if we maintain the illusion that a cultural product exists in itself, in a "neutral" form, before being incorporated into social power relations.

15. For this we use the Pearson's residual. It is based on the $\mathrm{khi}^{2}$ but instead of giving an overall measurement of the degree of association between two variables, it calculates the overrepresentation of each combination of categories (here, the variable class is crossed with all the active and supplementary variables of the MFA). This overrepresentation is generally considered significant if the value is over 1.96 but as this criteria is not very discriminating in our case we distinguish between the categories for which the coefficient is between 1.96 and 5, those for which it is between 5 and 10 and those for which it is over 10. Moreover, as part of the exploration of interactions between variables of position, we have created variables combining age, gender, and education either in pairs, or the three together (we will re-use them later). The results are presented in more detail in Appendix 2.

16. TF1 is the television channel with the highest number of viewers in France; it is free-to-air, although it is privately owned.

17. A weekly sports information programme.

18. Les Feux de l'amour in French.

19. A French soap opera.

20. Qui veut gagner des millions? 
21. The oldest gameshow on French TV, based on vocabulary and counting.

22. A Saturday night show with circus and music-hall acts.

23. France 3 is a public television channel focused on regional news, educational shows and games.

24. Known as "variété française".

25. The inclusion of questions on video games would probably add to this kind of analysis. Of respondents who used a computer in the last month, $28 \%$ did so to play video games. There is sizeable variation according to age (three times as many under-24-year-olds as over-55-year olds) and gender (37\% of men, $19 \%$ of women), but variation is relatively low according to education, then notably higher depending on socio-professional category, in favour of workers and artisans, shop owners, and business owners.

26. For an overview of popular leisure and cultural practices see Siblot, Cartier, Coutant, Masclet, Renahy (2015).

27. The main privately-owned subscription television channel in France, focused on sports, series, movies, and talk shows.

28. A daily show satirizing current affairs using puppets to parody public figures.

29. A show critically investigating the media.

30. Documentaries about daily life through a sociological lens.

31. A violinist who plays classical hits on television and mass concerts.

32. One of the first authors of comics or graphic novels to be recognised as an artist.

33. This might also be more due to a structural effect (the oldest are less educated but their qualifications are more distinctive) than to other effects. For example, it is perhaps not the same individuals who are older and less educated, although they are highly correlated through other variables. This is beyond the scope of this article however.

34. Another possibility was investigated here using linear regression models including interaction terms between education, gender, and age. The results confirm those presented here and are thus included in Appendix 2.

35. For each gender, we observe a "U distribution" of positions according to the level of education.

36. In a linear regression model, interaction effects refer to the fact that, for two independent variables $A$ and $B$, the effect of variable $A$ on a third variable $C$ changes depending on the value of variable $\mathrm{B}$.

\section{ABSTRACTS}

The notion of cultural legitimacy has had many incarnations and been subject to many criticisms over the years. However, few studies have set out to construct it empirically and quantify it at the national level and over several cultural practices. In spite of the intense theoretical debates, one question remains particularly neglected - given that the scale of cultural legitimacy is defined by the homology between the ordering of tastes and the ordering of social groups, which social space does it actually refer to? Here we propose an empirical approach to statistically account for the intersection of social power relations which many ethnographic studies have observed at the level of individuals and social groups. The goal is to analyse the relations between variables related to social status; education, age, and gender are the ones we look at 
here. We avoid the unfruitful trap of simply constructing hierarchies of effects, and instead consider the interactions between them. We therefore observe that, at the macro level where our analysis is situated, the scale of cultural legitimacy is simultaneously associated with the three social relations studied, opposing bourgeois (intellectual) culture to popular culture, feminine culture to masculine culture, and established culture to new emerging culture. Ultimately, the scale of cultural legitimacy is made up of three main echelons, associated with three configurations of social characteristics: intellectual, feminine, and established at the "top" of the legitimacy scale, intellectual, masculine, and emerging at the "middle" and, finally, popular, feminine, and established, at the "bottom". A sociological interpretation allows us to distinguish two variations of legitimate culture that are more or less well established, feminine, and intellectual, and three variations of illegitimate culture depending on gender and age variables (a taste for "outdated" or "sentimental" working class genres, a preference for "mass public" products that are widely available on radio, television, or in magazines, and a taste for emerging "virile" genres [science-fiction, rap, hard rock, etc.], that are sometimes constituted as juvenile subcultures subject to processes of legitimation). Beyond this nascent typology, we seek above all to establish the existence of these interactions, to propose certain statistical tools that are useful for studying them and to demonstrate the benefit of analysing the distribution of cultural practices in intersectional terms.

La notion de légitimité culturelle a connu de nombreuses déclinaisons et de nombreuses critiques. Pourtant, peu de travaux s'emploient à la construire de manière empirique et quantifiée à l'échelle d'un espace national et pour plusieurs pratiques culturelles. Malgré des débats théoriques intenses, une question demeure en particulier en jachère: l'échelle de légitimité culturelle étant définie par l'homologie entre l'ordonnancement des goûts et celui des groupes sociaux, de quel espace social est-il question? Nous proposons une démarche empirique pour tenir compte statistiquement de l'intersectionnalité des rapports sociaux de pouvoir, que de nombreuses enquêtes ethnographiques ont établie à l'échelle des individus et des groupes sociaux. Il s'agit essentiellement d'analyser les relations entre les variables de position sociale le diplôme, l'âge et le sexe, pour celles que nous retiendrons - sans tomber dans le piège improductif de la hiérarchisation des effets mais en les considérant plutôt en termes d'interactions. Nous établissons ainsi que, au niveau macro où se situe l'analyse, l'échelle de légitimité culturelle est associée simultanément aux trois rapports sociaux étudiés, opposant le bourgeois (lettré) au populaire, le féminin au masculin et l'ancien à l'émergent. Au final, l'échelle de légitimité est constituée de trois échelons principaux, associés à trois configurations de propriétés sociales : une culture lettrée, féminine et ancienne en « haut » de l'échelle, une culture lettrée, masculine et émergente au «milieu » et une culture populaire, féminine et ancienne en «bas ». L'interprétation sociologique permet ensuite de distinguer deux variations de la culture légitime, plus ou moins ancienne, féminine et lettrée, et trois variations de la culture illégitime en fonction des variables de sexe et d'âge : le goût pour les genres populaires «ringards » et «sentimentaux » se distingue du goût pour les produits « grand public » les plus accessibles par la radio, la télévision ou les magazines comme du goût pour les genres émergents et "virils » (science-fiction, rap ou hard rock...) qui sont parfois constitués en sous-cultures juvéniles et disponibles à des entreprises de légitimation. Au-delà de cette esquisse de typologie, nous cherchons surtout à établir l'existence de ces interactions, à proposer quelques outils statistiques utiles pour les étudier et à montrer l'intérêt qu'il y a à analyser la distribution des pratiques culturelles en termes intersectionnels. 


\section{AUTHORS}

\section{CAMILLE NOÛS}

Laboratoire Cogitamus

NICOLAS ROBETTE

École nationale de la statistique et de l'administration économique (ENSAE)-Institut

Polytechnique de Paris/Center for research in economics and statistics (Crest)

\section{OLIVIER ROUEFF}

CNRS/Centre de recherches sociologiques et politiques de Paris/Cultures et sociétés urbaines

(Cresppa-CSU) 